Provided for non-commercial research and education use. Not for reproduction, distribution or commercial use.

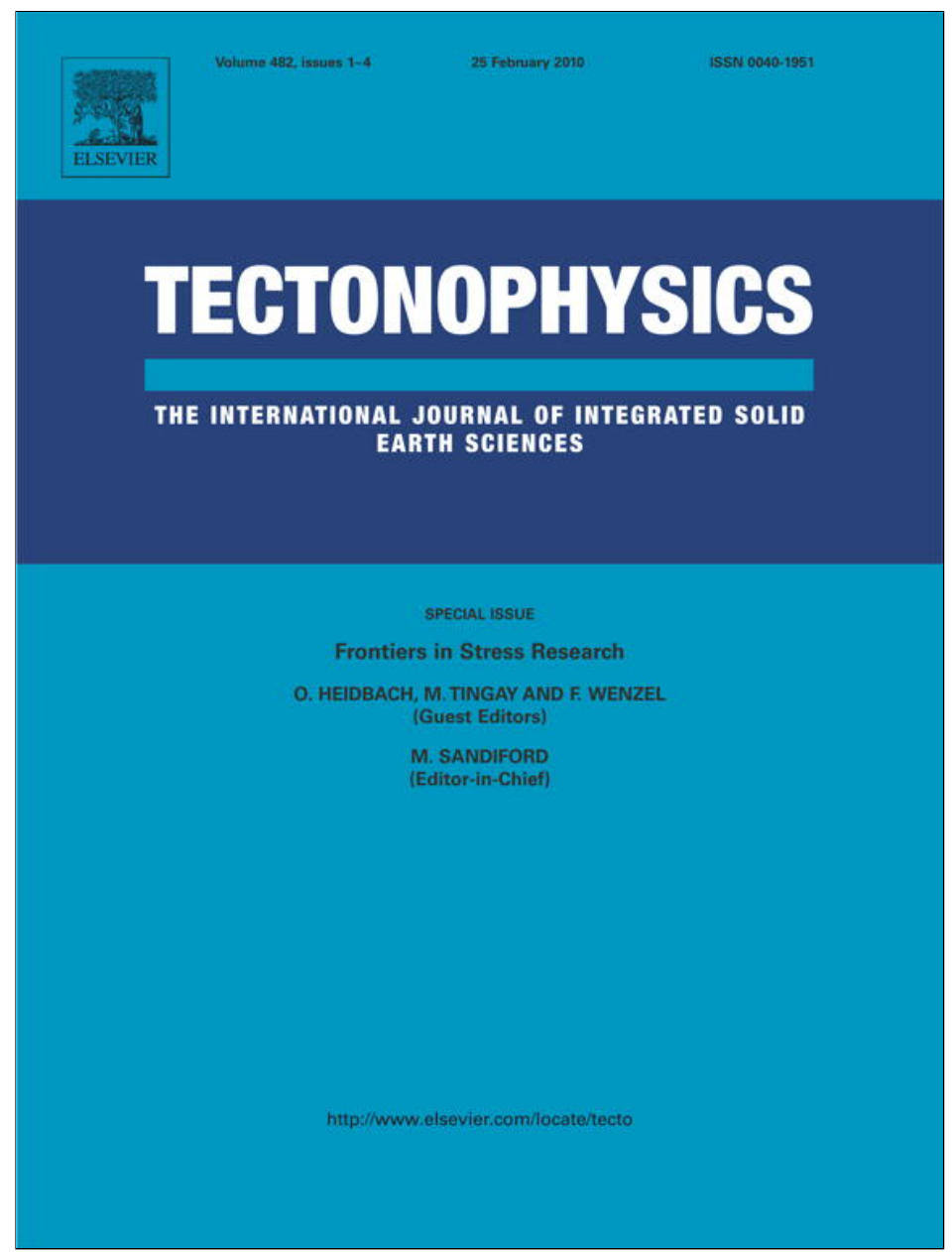

This article appeared in a journal published by Elsevier. The attached copy is furnished to the author for internal non-commercial research and education use, including for instruction at the authors institution and sharing with colleagues.

Other uses, including reproduction and distribution, or selling or licensing copies, or posting to personal, institutional or third party websites are prohibited.

In most cases authors are permitted to post their version of the article (e.g. in Word or Tex form) to their personal website or institutional repository. Authors requiring further information regarding Elsevier's archiving and manuscript policies are encouraged to visit:

http://www.elsevier.com/copyright 


\title{
Projection of mechanical properties from shallow to greater depths seaward of the Nankai accretionary prism
}

\author{
Maria V.S. Ask ${ }^{\mathrm{a}, *}$, Julia K. Morgan ${ }^{\mathrm{b}}$ \\ a Mining and Geotechnical Engineering, Luleå University of Technology, SE-971 87 Luleå, Sweden \\ b Department of Earth Science, Rice University, Houston, TX 77005, USA
}

\section{A R T I C L E I N}

\section{Article history:}

Received 19 September 2008

Received in revised form 21 July 2009

Accepted 19 August 2009

Available online 6 September 2009

\section{Keywords:}

Accretionary prism

Laboratory deformation

Consolidation

Overpressure

Ocean Drilling Program

\begin{abstract}
A B S T R A C T
Deformation processes in sediments at accretionary prisms are directly controlled by the state of effective in situ stress, the mechanical-, physical- and geochemical properties of the materials of the fault zone and surrounding wall rocks, as well as time. Measurements of these properties and their evolution in space and time, are therefore needed for a full understanding of the process of earthquake generation within subduction zones.

Reconsolidation tests have been carried out on Ocean Drilling Program cores collected from a reference site seaward of the active Nankai décollement zone off the southeast coast of Japan. The reconsolidation stress path subjects the samples to uniaxial strain deformation, which mimics their stress history, however at much higher loading rates than in the natural system. We have conducted two tests each from two mudstone samples within Lower Shikoku Basin. The samples were collected at 361 and $476 \mathrm{~m}$ below seafloor, on either side of the protodécollement horizon.

The objectives for mechanical testing are to probe the yield- and failure surfaces of these shallow sediments $(<0.5 \mathrm{~km}$ depth), and to project their mechanical properties from shallow to greater depths (several kilometers depth). This information is useful for making predictions about sediment response to accretion, underplating, and slip along the décollement. Because the tests were executed with a stress path that may approximate the stress history of the test samples, an additional objective is to estimate the effective in situ vertical stress, and to constrain the pore-fluid pressure at sample depth.

Considering their large scale behavior, our tests show that the samples collected above the protodécollement have higher strength than those below. We propose that cementation, microfabric and mineralogy of the sediments above the protodécollement result in a higher effective yield stress than predicted from effective in situ vertical stress at hydrostatic pore pressures. Sediments below the protodécollement, in contrast, are slightly underconsolidated, and provide an upper constraint on the magnitude of effective in situ vertical stress and pore-fluid pressure. We also used the test results to make initial predictions for the yield surface in 2D and 3D for sub-décollement samples across the margin. The construction of the 2D yield surface is the first attempt to quantify the model of sediment deformation proposed by Morgan et al. (2007). These results hint that the presence of cement has a strong, and increasing, influence on sediment behavior. Further testing is needed to verify these findings.
\end{abstract}

(c) 2009 Elsevier B.V. All rights reserved.

\section{Introduction}

Knowledge of the stress evolution and the current stress state in the Earth is of vital importance for the understanding of natural phenomena, for example earthquakes and slope failures. The understanding of the nature of stress and of stress paths that produce deformation in shallow rocks and sediments has advanced remarkably over the past decades, both from laboratory experiments and in situ stress measurements (e.g. Jones, 1994; Karig and Morgan, 1994;

\footnotetext{
* Corresponding author. Tel.: +46 92049 1411; fax: +46 920491935

E-mail address: Maria.Ask@ltu.se (M.V.S. Ask).
}

Dugan and Flemings, 2000; Karig and Ask, 2003). Results from consolidation experiments on undisturbed clay-rich sediment samples provide constraints on the state of effective in situ stress and the stress history, if testing is conducted carefully (e.g. Karig, 1993; Karig and Ask, 2003).

The Nankai accretionary margin, located southeast of Japan (Fig. 1) is the prime location to investigate earthquakes by scientific drilling, coring, sampling and monitoring physical and mechanical properties of sediments along the margin, and their influence of sliding behavior along the plate bounding fault (décollement) and other faults (e.g. Moore et al., 2001; Kimura et al., 2008). The goal of ongoing scientific drilling efforts by the Integrated Ocean Drilling Program (IODP) in the Nankai Trough is to reach the seismogenic zone, i.e. the earthquake-generating part of a 
A

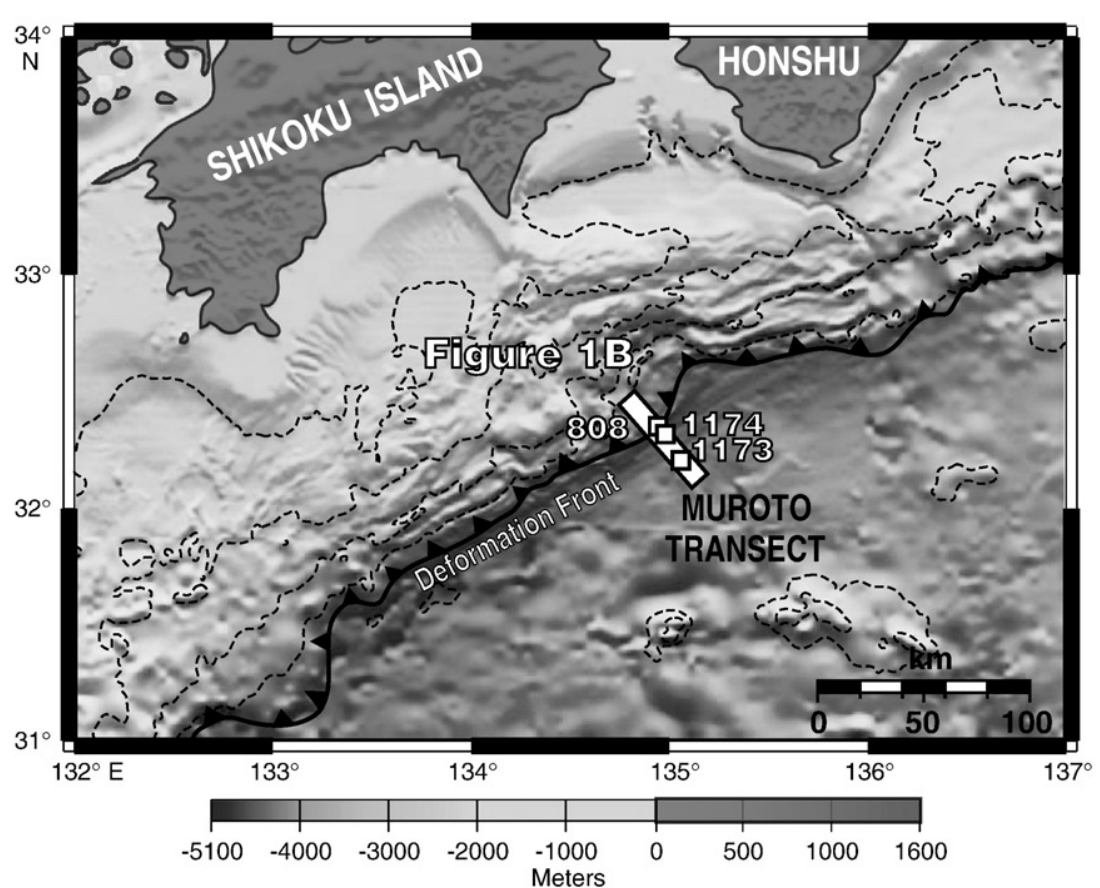

B

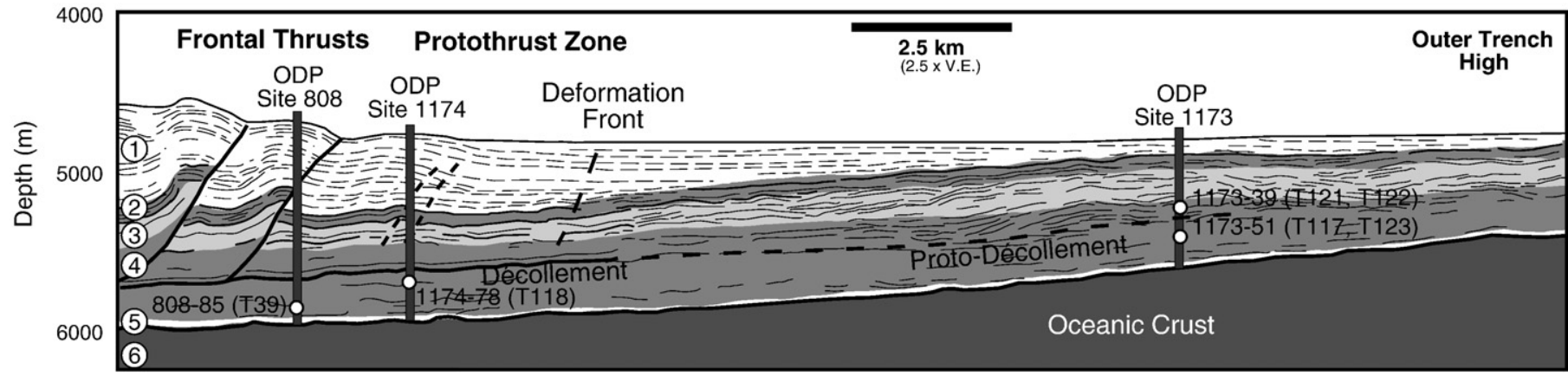

Fig. 1. A, Map of the Nankai Trough, including the location of Sites 1173,1174 and 808 . The white stripe indicates the location of a seismic reflection profile, part of which is interpreted in B. The deformation front passes between Site 1173 and Sites 1174 and 808. B, Interpreted cross-section across the toe of the Nankai accretionary prism, along the Muroto Transect. Simplified stratigraphy is indicated by numbered units: (1) and (2) Trench-Wedge facies, TWF; (3) Upper Shikoku Basin, USB; (4) and Lower Shikoku Basin, LSB; (5) Volcaniclastic Facies, VF; and (6) basaltic oceanic crust. The décollement zone lies within the Lower Shikoku Basin strata, and is correlated seaward of the deformation front along the protodécollement (modified from Morgan et al., 2007).

fault, at about $\sim 6000 \mathrm{~m}$ below seafloor (mbsf) (Tobin and Kinoshita, 2006).

Until now, however, scientific drilling operations in the Nankai accretionary prism have succeeded in penetrating the décollement zone only in shallow locations, in ODP Sites 808 and 1174, from 945-964 mbsf and 808-840 mbsf, respectively (Taira et al., 1991; Moore et al., 2001), well up-dip of the active seismogenic zone. The décollement-equivalent horizon (protodécollement) seaward of the accretionary deformation front has been drilled in ODP Site 1173 from 390-420 mbsf and in ODP Site 1177 from 400-449 mbsf (Moore et al., 2001). Thus, samples collected from these shallow locations provide information about the stress state and strength of sediments entering the subduction system, but cannot constrain their behaviors at greater depth where they can influence seismogenic behavior. However, we may be able to project observed trends in sediment properties to make informed inferences about deeper processes. In this study, we focus on several samples collected from ODP Site 1173 (Fig. 1), and compare them to previous results from samples collected down-dip beneath the prism.

We have conducted laboratory deformation experiments on several whole-round core samples from near the décollement and protodécollement along a transect across the Nankai accretionary prism. In particular, we tested two samples from either side of the protodécollement at Site 1173 (Fig. 1). Sediments below the protodécollement will eventually reach the depth of the seismogenic zone. In the absence of in situ samples, we can begin to project the mechanical response of these shallow samples ( $<500 \mathrm{mbsf}$ ) to greater depths (towards seismogenic depths) in 3D critical state models. The objectives of this paper are to (1) estimate the effective in situ vertical stress and pore-fluid pressure at the sample depths; (2) construct a preliminary critical state model and yield surface for sediments below the protodécollement, and (3) project the mechanical properties from shallow to greater depths.

\section{Nankai accretionary margin}

The Nankai margin has a long history of earthquakes over a range of scales, from damaging mega-earthquakes (e.g. Ando, 1982) to microearthquakes (e.g. Obara, 2002). The Nankai accretionary prism lies at the boundary between the Eurasian and Philippine Sea plates, off the southwest coast of Japan. The inactive Shikoku back-arc basin and overlying sediments are presently being subducted northwestward at a relative convergence rate of $\sim 2-4 \mathrm{~cm} / \mathrm{yr}$, normal to the margin (Seno et al., 1993). The incoming sedimentary section is dominated by bioturbated hemipelagic sediments of the Shikoku Basin 
sequence of Miocene to Quaternary age (e.g. Moore et al., 2001). The Shikoku Basin sequence comprises two facies: the Upper and Lower Shikoku Basin facies (USB and LSB, respectively), which are distinguished primarily by the presence of ash beds in the former. These sediments are overlain by younger deposits from the trench wedge; consisting of hemipelagic sediments interbedded with turbidite sand and ash layers.

The trench and basin sediments follow distinctive deformation pathways across the margin (e.g. Karig and Morgan, 1994; Morgan and Karig, 1995). Sediments seaward of the accretionary deformation front are deposited and consolidated in a basinal setting, and therefore subjected to a ductile uniaxial strain path with little to no lateral deformation (e.g. Karig and Morgan, 1994). Onset of tectonic deformation is marked by a protothrust zone (e.g. Moore et al., 1991), and imbricate thrust sheets mark the frontal portion of the prism (e.g. Gulick et al., 2004). The strata are partitioned into accreting and subducting packages, some of which may ultimately pass into the seismogenic zone (Karig and Morgan, 1994). The basal décollement extends beneath the prism and protothrust zone and lies entirely within the LSB facies; its seaward projection along the age-equivalent horizon is referred to as the protodécollement.

Fig. 2 shows the variation of shipboard porosity, $\eta$ with in situ effective vertical stress for hydrostatic pore pressure $\left(\sigma_{\mathrm{vh}}{ }^{\prime}\right)$ in Site 1173 (Table 1 includes all symbol definitions). Porosity decreases downward in the upper $102 \mathrm{mbsf}\left(\sigma_{\mathrm{vh}}{ }^{\prime}=0.6 \mathrm{MPa}\right)$, which consists of Quaternary hemipelagic mud and sandy to muddy turbidites of the outer Nankai Trench-Wedge facies. Porosity increases in the upper $50 \mathrm{~m}$ of the USB facies, which is followed by a nearly constant porosity range $(\eta=64-$
$68 \%$ ) to a depth of $\sim 325 \mathrm{mbsf}$ and $\sigma_{\mathrm{vh}}{ }^{\prime} \sim 0.6 \mathrm{MPa}$. Intergranular cement is believed to strengthen the sediment and impede the normal decrease in porosity in the USB unit (e.g. Karig, 1993; Shipboard Scientific Party, 2001). It has also been proposed that consolidation in the USB facies is prohibited by high overpressures (e.g. Bray and Karig, 1986). Porosities decrease rapidly to $~ 50 \%$ at the top of the LSB facies at $344 \mathrm{mbsf}$ $\left(\sigma_{\mathrm{vh}}{ }^{\prime}=2.0 \mathrm{MPa}\right)$, and a steady decline in porosity resumes to sub-bottom depth. The only exception to this trend is noted in the protodécollement zone (390-420 mbsf, or $\sigma_{\mathrm{vh}}{ }^{\prime}=2.4-2.5 \mathrm{MPa}$ ), where a minor shift in porosity range is observed, to $48-53 \%$.

The presence of limited evidence for brittle deformation in Site 1173 supports the assumption that the Site 1173 sediments have been deposited and consolidated in a basinal setting where ductile deformation by gravitational loading is assumed to control consolidation (e.g. Shipboard Scientific Party, 2001; Morgan et al., 2007). Sediment microfabrics change across the protodécollement horizon (Ujiie et al., 2003; Sunderland and Morgan, 2004; Morgan et al., 2007). Above the protodécollement zone at Site 1173, sediments exhibit a wide range of grain sizes and open, randomly oriented packets of clay minerals. Below the protodécollement horizon, clay minerals are typically larger than above and more uniform in size and shape. Ujiie et al. (2003) found fine-grained clay aggregates above and within the décollement horizon at Site 1173, which they interpreted to represent a bonding phase. The clay mineralogy varies with depth at Site 1173, with smectite being the most abundant clay-sized mineral followed by illite and chlorite (+ kaolinite) (Steurer and Underwood, 2003a). The thermal gradient results in a gradual transformation of smectite to illite with depth (e.g. Steurer and Underwood, 2003a; Spinelli et al.,

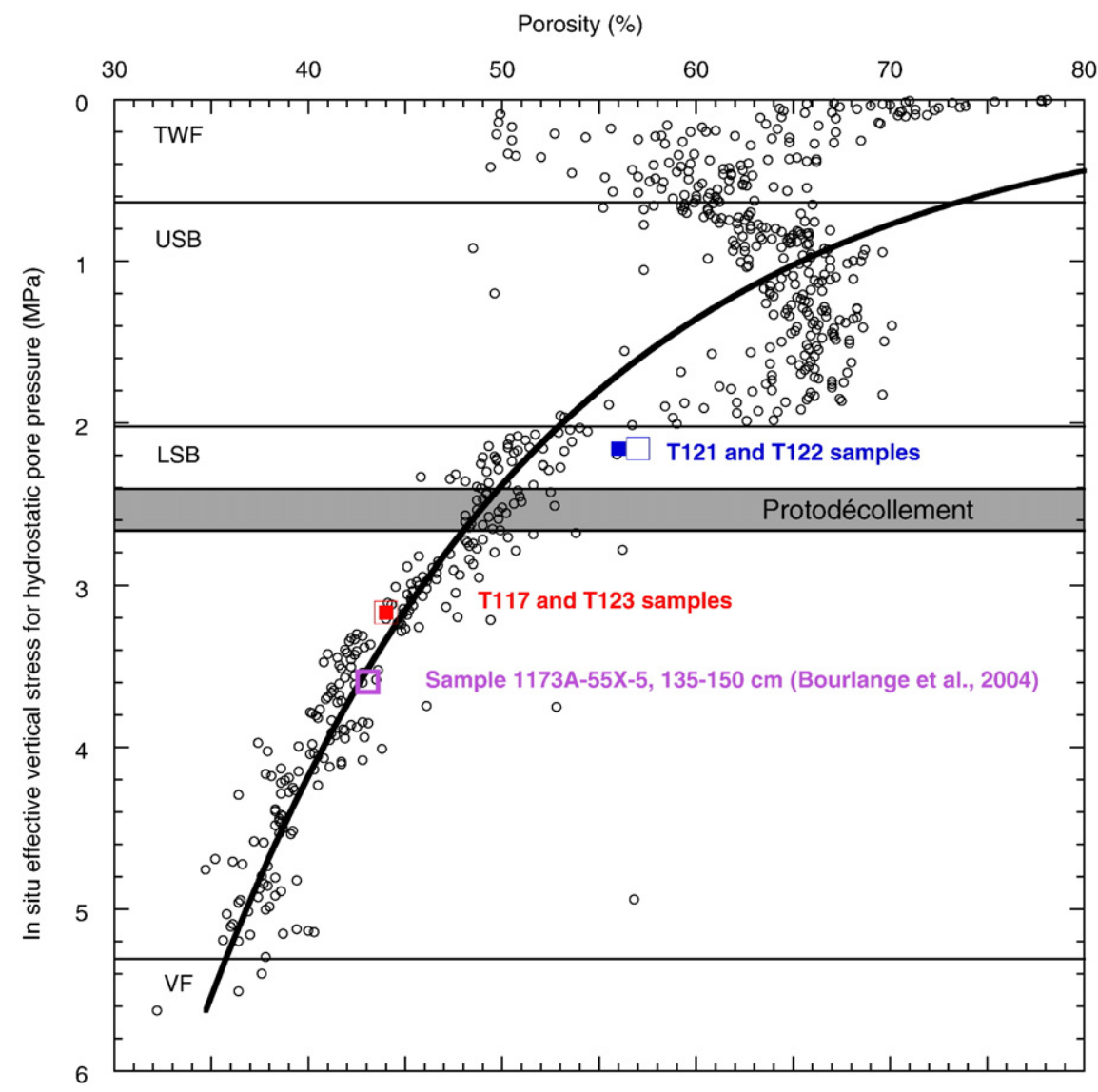

Fig. 2. Site 1173 shipboard porosities, $\eta$ plotted against effective in situ vertical stress for hydrostatic pore pressure $\sigma_{\mathrm{vh}}$ '. The location and approximate thickness of the protodécollement horizon is shown together with the lithologic facies. Abbreviations are the same as in Fig. 1 . The solid line is the best fit porosity-stress relationship $(\eta=65.4$ $\left.-40.9 \log \left(\sigma_{\mathrm{vh}}{ }^{\prime}\right)\right)$ that is derived for porosities from the LSB facies at Site 1173 (Morgan and Ask, 2004). The initial porosities of the four test samples are also included, where the open blue square is test T121, the filled blue square is test T122, the open red square is test $\mathrm{T} 117$, and the filled red square is test $\mathrm{T} 123$ (cf. Table 2 ). The initial porosity of the tested sample by Bourlange et al. (2004) is included in open purple square. 
Table 1

Definition of common symbols used in text.

\begin{tabular}{|c|c|}
\hline Symbol & Definition \\
\hline$\beta$ & Angle to the horizontal of shear fracture, ${ }^{\circ}$ \\
\hline$\Delta \sigma$ & Differential stress', MPa, $\Delta \sigma=\sigma_{\mathrm{v}}{ }^{\prime}-\sigma_{\mathrm{h}}{ }^{\prime}$ \\
\hline$\Delta \sigma_{\text {peak }}$ & Peak strength in tests, MPa \\
\hline$e$ & Void ratio, dimensionless, $e=\eta /(100-\eta)$ \\
\hline$\varepsilon_{\mathrm{h}}^{\mathrm{av}}$ & Average horizontal strain, \% \\
\hline$\varepsilon_{\mathrm{v}}$ & Vertical strain, \% \\
\hline$\varepsilon_{\mathrm{vol}}$ & Volumetric strain, \% \\
\hline$\phi^{\prime}$ & Effective friction angle, ${ }^{\circ}, \phi^{\prime}=2 \cdot(\beta-45)$ \\
\hline$\eta$ & $\begin{array}{l}\text { Sediment porosity, } \%, \eta=\text { volume of pore fluid/total volume }= \\
\left(\rho_{\mathrm{g}}-\rho_{\mathrm{b}}\right) /\left(\rho_{\mathrm{g}}-\rho_{\mathrm{w}}\right) \cdot 100\end{array}$ \\
\hline$H$ & depth below sea level, $\mathrm{m}$ \\
\hline$K_{0}$ & Stress ratio during uniaxial strain, dimensionless, $K_{0}=\Delta \sigma_{\mathrm{h}}{ }^{\prime} / \Delta \sigma_{\mathrm{v}}{ }^{\prime}$ \\
\hline$\lambda_{*}^{\min }$ & Minimum overpressure ratio, dimensionless, $\lambda_{*}^{\min }=P_{*}^{\min } / \sigma_{\mathrm{vh}}{ }^{\prime}$ \\
\hline$M$ & $\begin{array}{l}\text { Critical stress state ratio, dimensionless, } \\
M=\Delta \sigma / \sigma_{\mathrm{m}}{ }^{\prime}=6 \cdot \sin \phi^{\prime} /\left(3-\sin \phi^{\prime}\right)\end{array}$ \\
\hline$\mu$ & Friction coefficient, dimensionless, $\mu=\tau / \sigma_{\mathrm{n}}{ }^{\prime}=\tan \phi^{\prime}$ \\
\hline OCR & Overconsolidation ratio, dimensionless, $O C R=\sigma_{\mathrm{y}}{ }^{\prime} / \sigma_{\mathrm{vh}}{ }^{\prime}$ \\
\hline$P_{*}$ & Excess pore-fluid pressure, MPa, $P_{*}=P_{\mathrm{f}}-P_{\mathrm{w}}$ \\
\hline$P_{*}^{\min }$ & $\begin{array}{l}\text { Minimum pore-fluid pressure in excess of hydrostatic } \\
\text { water pressure, } \mathrm{MPa}, P_{*}^{\min }=\sigma_{\mathrm{vh}}{ }^{\prime}-\sigma_{\mathrm{y}}{ }^{\prime}\end{array}$ \\
\hline$P_{\mathrm{f}}$ & Total pore-fluid pressure acting on sediment, MPa \\
\hline$P_{\mathrm{w}}$ & Hydrostatic fluid pressure acting on sediment, $\mathrm{MPa}, P_{\mathrm{w}}=\rho_{\mathrm{w}} \cdot g \cdot H$ \\
\hline$\rho_{\mathrm{b}}$ & Sediment bulk density, $\mathrm{g} / \mathrm{cm}^{3}$, total weight/total volume \\
\hline$\rho_{\mathrm{w}}$ & Sediment grain density, $\mathrm{g} / \mathrm{cm}^{3}$ \\
\hline$\rho_{\mathrm{w}}$ & Seawater density, $\mathrm{g} / \mathrm{cm}^{3}, \rho_{\mathrm{w}}=1.035 \mathrm{~g} / \mathrm{cm}^{3}$ \\
\hline$\sigma_{\mathrm{h}}^{\prime}$ & Effective horizontal stress, MPa \\
\hline$\sigma_{\mathrm{m}}^{\prime}$ & Effective mean stress, MPa, $\sigma_{\mathrm{m}}{ }^{\prime}=\left(\sigma_{\mathrm{v}}{ }^{\prime}+2 \cdot \sigma_{\mathrm{h}}{ }^{\prime}\right) / 3$ \\
\hline$\sigma_{\mathrm{n}}^{\prime}$ & Normal effective stress, MPa \\
\hline$\sigma_{\text {peak }}{ }^{\prime}$ & Effective vertical peak stress, MPa \\
\hline$\sigma_{\mathrm{v}}$ & Total vertical stress, $\mathrm{MPa}, \sigma_{\mathrm{v}}=\left(\rho_{\mathrm{b}}-\rho_{\mathrm{w}}\right) \cdot g \cdot z+P_{\mathrm{w}}$ \\
\hline$\sigma_{\mathrm{v}}^{\prime}$ & Effective vertical stress, $\mathrm{MPa}, \sigma_{\mathrm{v}}{ }^{\prime}=\sigma_{\mathrm{v}}-P_{\mathrm{f}}=\left(\rho_{\mathrm{b}}-\rho_{\mathrm{w}}\right) \cdot g \cdot z+P_{*}$ \\
\hline$\sigma_{\mathrm{v}^{*}}$ & Effective in situ vertical stress, MPa, $\sigma_{\mathrm{v}^{*}}{ }^{\prime}=\sigma_{\mathrm{vh}}{ }^{\prime}-P_{*}$ \\
\hline$\sigma_{v^{*}}^{\max }$ & Maximum effective in situ vertical stress, MPa, $\sigma_{\mathrm{v}^{*}}^{\max }=\sigma_{\mathrm{vh}}{ }^{\prime}-P_{*}^{\min }$ \\
\hline$\sigma_{\mathrm{vh}}{ }^{\prime}$ & $\begin{array}{l}\text { Effective in situ vertical stress for hydrostatic pore pressure, } \\
\mathrm{MPa}, \sigma_{\mathrm{vh}}{ }^{\prime}=\sigma_{\mathrm{v}}-P_{\mathrm{w}}=\left(\rho_{\mathrm{b}}-\rho_{\mathrm{w}}\right) \cdot g \cdot \mathrm{z}\end{array}$ \\
\hline$\sigma_{\mathrm{y}}^{\prime}$ & Effective vertical yield stress MPa \\
\hline$\tau$ & Shear stress, $\mathrm{MPa}$ \\
\hline$z$ & burial depth in meters below seafloor (mbsf) \\
\hline
\end{tabular}

2007). The highest amount of smectite is measured at $\sim 380 \mathrm{mbsf}$, near the top of LSB (344 mbsf). Results from the inversion of 3D seismic reflection data at Site 1173 suggest that a compacted layer has developed between the USB/LSB facies boundary and the protodécollement that may correlate with this diagenetic boundary, and associated porosity change (Bangs and Gulick, 2005).

\section{Methods and materials}

\subsection{Theory}

Laboratory deformation experiments are used to subject representative sediments to varying stress and strain conditions to better isolate functional dependencies. However, there are limitations to direct comparisons between laboratory and natural systems (e.g. Karig and Morgan, 1994; Jones, 1994): (1) laboratory experiments require much faster strain rates than are typical in nature; (2) it is difficult to reproduce natural diagenetic processes in the laboratory, particularly during short-duration experiments; and finally, (3) only simple stress paths can be applied in laboratory experiments which may not represent natural stress paths. The last limitation can be accounted for to some extent by conducting multiple tests on samples with different orientation and stress paths.

In general, the response of fine-grained sediments to laboratory deformation can be described by critical state soil mechanics (e.g. Schofield and Wroth, 1968; Atkinson and Bransby, 1978; Wood, 1990; Jones, 1994). The concept of critical state provides a framework for sediment behavior, from deposition until diagenetic cementation turns the sediment into a lithified rock (Jones, 1994). Three principal quantities are used to represent the state and evolution of the sediment, i.e., effective mean stress $\left(\sigma_{\mathrm{m}}^{\prime}\right)$, differential stress $(\Delta \sigma)$, and a volumetric parameter (e.g. $\eta$ or void stress ratio, $e$; cf. Table 1 ). The path of the sediment through the three dimensional space defined by these parameters is used to predict the material behavior, and in particular, the yield and failure conditions for a given set of values. The stress path is commonly projected into one of several 2D plots (Fig. 3). Laboratory deformation experiments on undisturbed, homogeneous sediment can help to determine three key properties for that material, specifically, the critical state line (CSL), the yield surface, and the natural stress path.

The critical state is a condition of perfect plasticity, when plastic shearing can occur indefinitely without changes in volume or effective stress (e.g. Wood, 1990). The critical state corresponds to a residual strength condition for many types of sediment (e.g. Farmer, 1983; Leddra et al., 1992), and thus may be equated to fault or detachment slip during earthquakes and landslides (Jones, 1994). The CSL and its

\section{A}
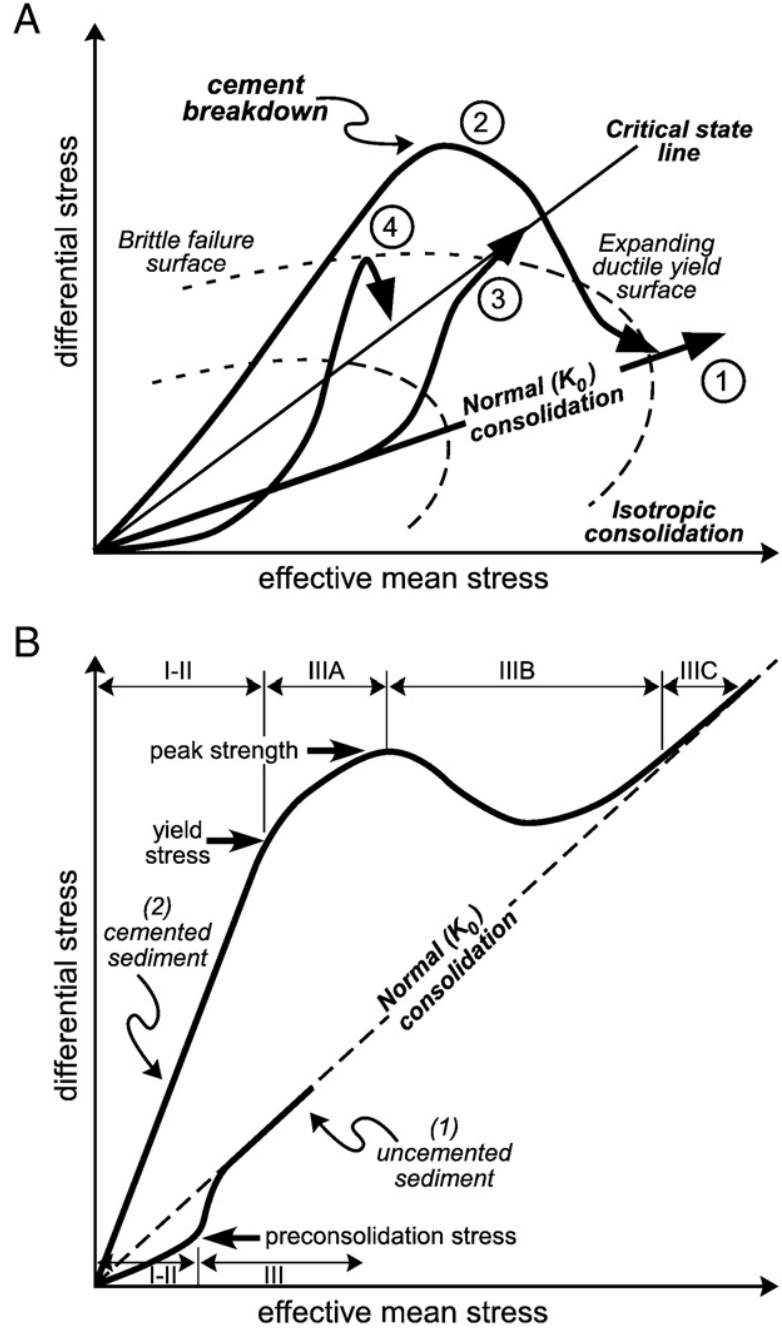

Fig. 3. Schematic plots of effective mean stress $\left(\sigma_{\mathrm{m}}{ }^{\prime}\right)$ and differential stresses $(\Delta \sigma)$. A, A suite of laboratory deformation experiments may be used to constrain the yield envelope. Four hypothetical stress paths (numbers within circles) are shown: (1) normal $\left(K_{0}\right)$ consolidation (uniaxial strain) stress path of uncemented sample; (2) $K_{0}$ reconsolidation (uniaxial strain) stress path of cemented sample; (3), ductile (compactive) yield to failure along the critical state line (CSL) (4), "overconsolidated" elastic sediments, reloaded to brittle failure. B, Reconsolidation experiments for normally consolidated (1) and cemented (2) sediment. The plot of $\sigma_{\mathrm{m}}$ ' versus $\Delta \sigma$ is sensitive to changes in sediment stress state. Path (1) of uncemented sediment is marked by initially low elastic slope followed by yield and return to normal consolidation trend; path (2) of cemented sediment shows a more rapid rise in $\Delta \sigma$, precursory yield at $\sigma_{\mathrm{y}}^{\prime}$, leading to peak strength, $\sigma_{\text {peak }}$ at $\Delta \sigma_{\text {peak }}$, and finally strain softening as the sample returns to a normal consolidation trend (from Morgan et al., 2007) 
downward extension onto the volumetric plane serves to partition the sediment response into brittle and ductile modes, corresponding to dilative and contractive deformation, respectively. Determination of the CSL is made by carrying out a suite of experiments on homogeneous sediment to critical state at different stress states.

The yield surface marks the boundary between elastic and plastic deformation of the sediment and records some measure of the previous maximum stress state the sediment has experienced. The yield surface is also separated into brittle and ductile parts, referred to as the Hvorslev and Roscoe surfaces, respectively. The projected geometry of the yield surface in $\Delta \sigma-\sigma_{\mathrm{m}}^{\prime}$, is thought to be elliptical and centered on the natural stress path (e.g. Wood, 1990; Jones, 1994; Fig. 3A). As the sediment is subjected to higher stress states, the yield surface expands self-similarly along the natural stress path, reflecting the increase in strength that tracks decreasing specific volume. The shape of the yield surface can be constrained from multiple laboratory deformation tests on homogeneous subsamples that are subjected to different stress paths, if they are started within the yield surface. Each test will produce a yield point where sediment response changes from elastic to plastic. The stress path traces the stress history of the sediment in a stress path diagram of $\Delta \sigma$ versus $\sigma_{\mathrm{m}}{ }^{\prime}$ (Fig. $3 \mathrm{~A}$ ). Each point on the stress path can be thought of as directly equivalent to a Mohr's stress circle, with $\Delta \sigma$ and $\sigma_{\mathrm{m}}$ ' defining the diameter and the center of the stress circle (e.g. Farmer, 1983; Jones, 1994). Two common stress paths applied in geotechnical- and rock mechanical testing are triaxial and isotropic stress paths. A triaxial stress path at low axial stress and constant confining pressure can result in brittle (i.e., localized) deformation of the sample when the path encounters the Hvorslev surface, leading to the formation of a shear fracture. The effective friction angle, $\Phi^{\prime}$ and corresponding friction coefficient, $\mu$ can be calculated from the angle to the horizontal of the shear fracture $\beta$ (Table 1). The isotropic stress path causes ductile (i.e., distributed) deformation and contraction of the sample with increasing axial stress and confining pressure, as the stress path passes through the Roscoe surface.

Natural stress paths may be difficult to reproduce in the laboratory. One exception is the $K_{0}$ reconsolidation stress path, which often is assumed to mimic the ductile deformation of uniaxial strain that occur in areas dominated by self-weight loading, i.e. ocean basins. Fig. 3B shows schematic responses of two types of samples in the $\sigma_{\mathrm{m}}{ }^{\prime}-\Delta \sigma$ plane that are subjected to a $K_{0}$ reconsolidation stress path. The dramatically different mechanical behavior of the two samples is due to diagenetic differences, one sample is uncemented, whereas the other is cemented. The process of cementation is also termed structuration, bonding, or diagenesis (e.g. Bjerrum, 1973), and refers to various diagenetic processes, for example secondary mineralization and intergranular chemical effects (e.g. Burland, 1990). It imparts a component of strength to the sediment, in addition to that developed by mechanical consolidation, and to some extent it opposes the effects of overpressure and secondary consolidation (e.g. O'Brien et al., 1989; Tribble and Wilkens, 1994). Fig. 3B also shows the phases a cemented sample undergoes during a $K_{0}$ reconsolidation test (Morgan and Ask, 2004): (I) isotropic consolidation; (II) elastic uniaxial consolidation; (IIIA) plastic uniaxial consolidation up to sediment peak strength (work-hardening); (IIIB) plastic uniaxial consolidation while cement breaks down (worksoftening); and (IIIC) plastic uniaxial consolidation at normal consolidation (work-hardening). The slope of the $\sigma_{\mathrm{v}}{ }^{\prime}-\sigma_{\mathrm{h}}{ }^{\prime}$ plot in phase II defines the elastic stress ratio, $K_{0}$ elastic (Table 1 ). Corresponding section of the plot in phase IIIC defines to the plastic stress ratio, $K_{0}$ plastic, which depends on the lithology of the sediment, its grain fabrics, and previous stress history (e.g. Jones, 1994).

During the $K_{0}$ reconsolidation stress path for a clay-rich sediment, the yield stress, $\sigma_{\mathrm{y}}{ }^{\prime}$ is a measure of the effective in situ vertical stress. By relating $\sigma_{\mathrm{y}}^{\prime}$ to the effective vertical hydrostatic stress, $\sigma_{\mathrm{vh}}$ ', several parameters can be estimated, for example the overconsolidation stress ratio, $O C R$, minimum pore-fluid pressure in excess of hydrostatic water pressure, $P_{*}^{\min }$, maximum effective vertical stress, $\sigma_{\mathrm{v}^{*}}^{\max }$, and minimum value of overpressure stress ratio, $\lambda_{*}^{\text {min }}$. The relationships for these parameters are listed in Table 1 , and discussed further by Morgan and Ask (2004) and Flemings et al. (2008). We estimate the value of $\sigma_{\mathrm{vh}}$ ' by integrating the densities of the overburden at a given depth, assuming there are no excess pore pressures acting on the sediment (Table 1). For uncemented samples, several methods exist to define the preconsolidation pressure (e.g. Casagrande, 1936; Becker et al. 1987; Wang and Frost, 2004). For cemented sediments, the yield stress is the geometrical equivalent of the preconsolidation pressure (Jones, 1994). Because the samples of this study appear to be cemented, we have adopted the approach of Karig (1993). He used various relationships among the collected data to define the yield stress at the point where the rate of deviation from the elastic slope began to change rapidly (c.f. Figs. 7, 8). Morgan and Ask (2004) and Morgan et al. (2007) correlated the peak differential strength, i.e. the effective vertical peak stress, $\sigma_{\text {peak }}$ ' to the cementation enhanced "preconsolidation" pressure, and compared that to hydrostatic effective vertical stress from porosities, to infer enhanced strength.

\subsection{Testing set-up and procedure}

The equipment consists of a triaxial cell mounted in a computercontrolled servo-hydraulic INSTRON 1324 load frame (cf. Fig. 9 of Morgan and Ask, 2004). It employs four controllers that can alter the effective stress state in the triaxial cell: stroke, load, confining pressure, and pore-fluid pressure. A dedicated computer software program

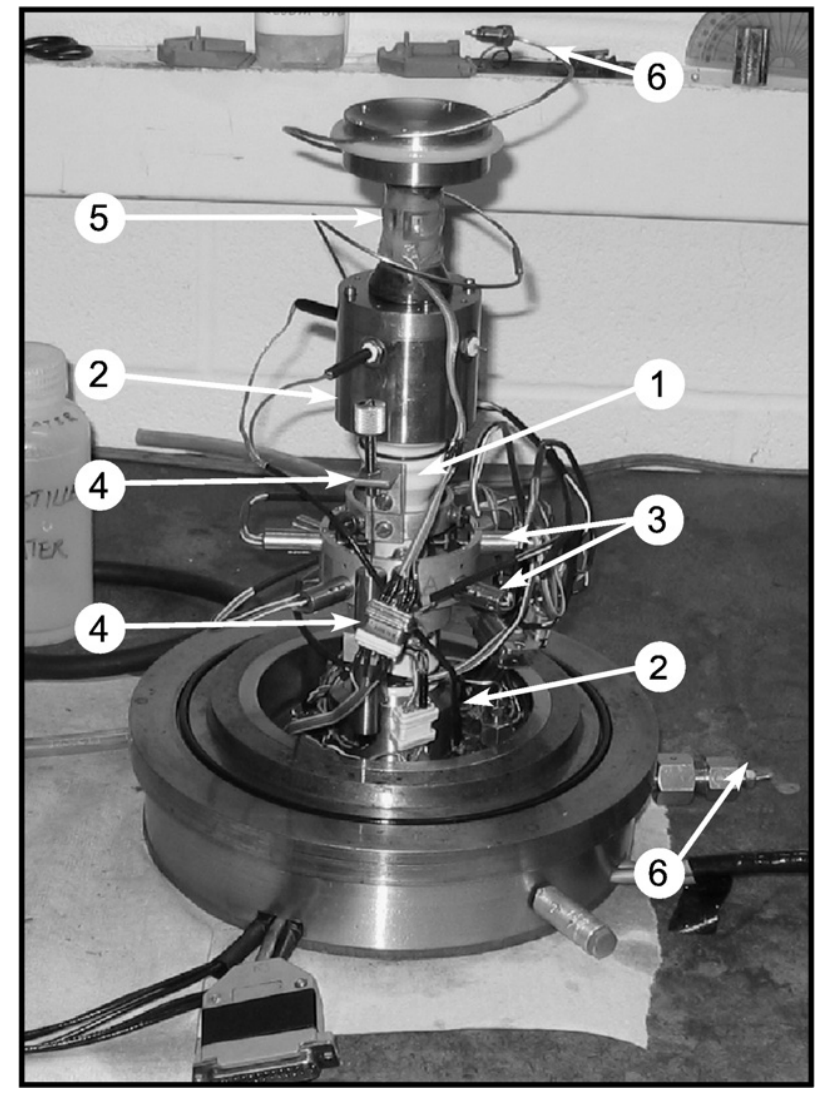

Fig. 4. Photograph of experimental set-up of Test 121. Sample is mounted within a latex jacket (1) and between the upper and lower platens (2). Horizontal strains are measured across four pairs of linear variable transducers (LVDTs) in a ring at sample midsection (3). Vertical strains are measured by one pair of LVDTs attached to rings spanning the central section of the sample (4). Differential stress is measured by a load cell (5) mounted under the upper platen (2). Pore fluid can drain from either or both ends of the sample (6). 
commands the stroke, load, and confining pressure controllers to execute a chosen stress path, whereas the pore-fluid pressure controller is set at a constant pore-fluid pressure that is manually monitored during testing. Horizontal strains are measured by an array of eight linear variable digital transducers (LVDT's) across four diameters at the mid-height of the sample (Fig. 4). One pair of LVDT's measures the vertical strain over the middle half of the sample, one LVDT mounted outside the triaxial cell measures the external vertical strain, and one external LVDT mounted on the pore-fluid pressure intensifier measures the change in pore-fluid volume. A latex jacket isolates the sample from the silicon oil confining fluid, and two 1-mm thick titanium filters isolates the sample from the pore-fluid drains at both ends of the sample. Testing was conducted under fully drained conditions, with the pore-fluid being allowed to drain in and out through both ends of the sample. A total of 11 digitized channels monitored loading and dimensional data were saved every 15 or 30 min during testing, providing detailed information about sample deformation and strength.

We used the same test equipment, established the same testing conditions and applied the same stress paths as Karig (1993), with four minor differences. First, no velocity data were collected due to technical difficulties. Second, no permeability measurements were made, due to time considerations, and thus no constant-head permeability test were conducted during the initial test phase. Third, we used fresh water as pore-fluid instead of water with seawater salinity. This difference does not affect test results in any way, as pore fluids are continuously expelled from the sample during a $K_{0}$ reconsolidation test. Fourth, our tests were carried out at a slower deformation rate $(11.5 \mathrm{~Pa} / \mathrm{s})$ than those by Karig (1993), who used a deformation rate of $17.3 \mathrm{~Pa} / \mathrm{s}$. This lower rate proves to produce more stable test conditions during $K_{0}$ reconsolidation, because the computer algorithm is better able to maintain a constant cross-sectional area. Deformation rates for both our tests and those of Karig (1993) were low enough to prevent the build-up of overpressure during testing. Hence, we use the same test conditions as Morgan and Ask (2004). However, the pore-fluid pressure intensifier was repaired before test T121 was started.

The testing sequence included a preconsolidation phase, which lasted at least $20 \mathrm{~h}$, at constant vertical and horizontal stresses of about 1.7 $\mathrm{MPa}$ and a back pore pressure of $1.03 \mathrm{MPa}$. During this phase, the sample is brought to a uniform hydrostatic stress state in order to ensure that all remaining gases in the system are in solution. (Karig, 1993). The preconsolidation phase is ended once all recorded parameters reveal stable values. The pore-fluid pressure was checked manually at least 10 times each day. During test T117, pore-fluid pressure was rarely adjusted. On the other hand, it was often corrected during tests T121T123. We noted larger pore-fluid pressure excursions than normal, in the range from 1.00 to $1.06 \mathrm{MPa}$. Unfortunately, pore-fluid pressure data are not collected; hence, the effective stress calculations may be faulty, based on the observed excursions, by up to $0.06 \mathrm{MPa}$. Each sample was first brought to a uniform isotropic stress state to ensure that all remaining gases in the system were in solution during the test phase. The reconsolidation phase began immediately after the preconsolidation phase, and followed a $K_{0}$ reconsolidation computer-controlled stress path: vertical stress was increased at a constant rate $(11.5 \mathrm{~Pa} / \mathrm{s})$, while the horizontal stress (confining pressure) was adjusted by computer control to maintain a constant cross-sectional area of the sample. This load rate is sufficiently low to maintain fully drained conditions, hence to allow dissipation of internal pore pressure during testing. At the outset of the $K_{0}$ reconsolidation test, the sudden change in stress state from initially isotropic stresses to $K_{0}$ reconsolidation leads to minor boundary effects. System compliance effects and closure of micro-cracks can also affect the response during the initial phase of $K_{0}$ reconsolidation tests. The initial stress conditions of all tests were almost identical, with starting values of $\sigma_{\mathrm{m}}$ ' and $\Delta \sigma$ within the ranges $0.74-$ 0.76 MPa and 0.14-0.17 MPa, respectively (Table 2). However, electrical instability as the test turned into computer-control after the first reading induces small random shifts in the stress state.
Table 2

Principal values and results of sample tests.

\begin{tabular}{|c|c|c|c|c|}
\hline & \multicolumn{4}{|l|}{ Test } \\
\hline & $\mathrm{T} 121$ & T122 & T117 & T123 \\
\hline $\begin{array}{l}\text { Whole-round core ID: } \\
190-1173 \mathrm{~A}-(\mathrm{cm})\end{array}$ & \multicolumn{2}{|l|}{ 39X-1, 76-99 } & \multicolumn{2}{|c|}{$51 X-2,42-64$} \\
\hline Sample ID: 190-1173A- (cm) & $39 X-1,80-86$ & $39 X-1,80-86$ & $51 X-2,57-64$ & $51 X-2,50-56$ \\
\hline Depth (mbsf) & 360.74 & 360.74 & 476.34 & 476.41 \\
\hline $\begin{array}{l}\text { Depth from top of } \\
\text { protodécollement zone }(\mathrm{m})\end{array}$ & $\begin{array}{l}29 \mathrm{~m} \\
\text { above }\end{array}$ & $\begin{array}{l}29 \mathrm{~m} \\
\text { above }\end{array}$ & $\begin{array}{l}56 \mathrm{~m} \\
\text { below }\end{array}$ & $\begin{array}{l}56 \mathrm{~m} \\
\text { below }\end{array}$ \\
\hline Initial porosity (\%) & 57 & 56 & 44 & 44 \\
\hline$\sigma_{\mathrm{vh}}^{\prime}(\mathrm{MPa})$ & 2.2 & 2.2 & 3.3 & 3.3 \\
\hline Type of yield & Ductile & Brittle & Ductile & Brittle \\
\hline$\sigma_{\mathrm{y}}^{\prime}(\mathrm{MPa})$ & $3.25 \pm 0.10$ & $3.01 \pm 0.01$ & $2.95 \pm 0.08$ & $2.30 \pm 0.01$ \\
\hline$\Delta \sigma_{\text {peak }}(\mathrm{MPa})$ & - & 2.51 & 1.71 & 1.70 \\
\hline$K_{0}$ elastic $(-)$ & 0.17 & 0.11 & 0.46 & 0.28 \\
\hline$K_{0}$ primary $(-)$ & - & - & 0.82 & - \\
\hline$\beta\left({ }^{\circ}\right)$ & 47 & 65 & - & 67 \\
\hline$\Phi^{\prime}\left({ }^{\circ}\right)$ & 4 & 40 & - & 44 \\
\hline$\mu(-)$ & 0.07 & 0.84 & - & 0.97 \\
\hline OCR $(-)$ & 1.5 & 1.4 & 0.9 & 0.7 \\
\hline$P^{\min }(\mathrm{MPa})$ & -1.1 & -0.8 & 0.4 & 1.0 \\
\hline$\lambda^{\min }(-)$ & -0.5 & -0.4 & 0.1 & 0.3 \\
\hline$\sigma_{\mathrm{v}^{*}}^{\max }(\mathrm{MPa})$ & 3.3 & 3.0 & 2.9 & 2.3 \\
\hline
\end{tabular}

\subsection{Samples}

The whole-round core samples for this study were collected from either side of the protodécollement zone in Site 1173, at 361 and $476 \mathrm{mbsf}$, respectively (Table 2). The whole-round core samples were carefully sealed and stored in a refrigerator at $+5^{\circ} \mathrm{C}$ with high humidity. Cylindrical test samples were cored with a water-lubricated rotary coring tube from the whole-round core samples. Visual inspection of the whole-round sample revealed no drilling disturbances, so it was assumed that the sample was undisturbed. This was later confirmed by CT scans of the whole-round core samples. All subsamples for testing had diameters of $\sim 20 \mathrm{~mm}$ and heights of $\sim 50-55 \mathrm{~mm}$ (i.e., at least $\sim 2.5$ times the diameter). Initial bulk densities were calculated from measurements of wet volumes and wet weights of the samples, and porosities were derived from bulk density values and shipboard values of grain- and water densities. Fig. 2 shows that there is fairly good correlation between the shipboard and shore-based porosity values. Note that the shallower two subsamples have similar porosities as that of one adjacent shipboard sample, but that the general trend of shipbased samples reveals significantly lower porosities. Table 2 summarizes the subsample properties.

Subsamples were taken from each of the two whole-round cores for X-ray diffraction analyses (XRD), microfabric studies on the undeformed sediments in a scanning electron microscope (SEM), and, on the deep sample, grain-size analyses. In the XRD analyses, the relative abundances (weight percent) by SVD factors of smectite, illite, chlorite (and kaolinite), and quartz were calculated (Steurer and Underwood, 2003a). Steurer and Underwood (2003a) propose that the smectite-illite diagenesis in Site 1173 begins near the upper limit of the protodécollement zone, at $\sim 390$ mbsf. They measured significantly higher abundances of smectite and quartz in the shallower whole-round core sample than in the deeper one (Fig. 5). On the other hand, they obtained higher abundances of illite and chlorite in the deeper sample than in the shallower one. The SEM analyses also point toward different microfabrics and microstructures in the two samples (Sunderland and Morgan, 2004; Morgan et al., 2007). The shallow sample consists of stacked aggregates that are separated by more randomly oriented particles (Fig. 6A). In addition, a fine-grained clay phase appears dispersed throughout the samples and adhering to the surfaces of larger grains (Sunderland and Morgan, 2004). The deeper sample is characterized by a more uniform grain size of the clay particles, with moderate clay preferred orientation and 


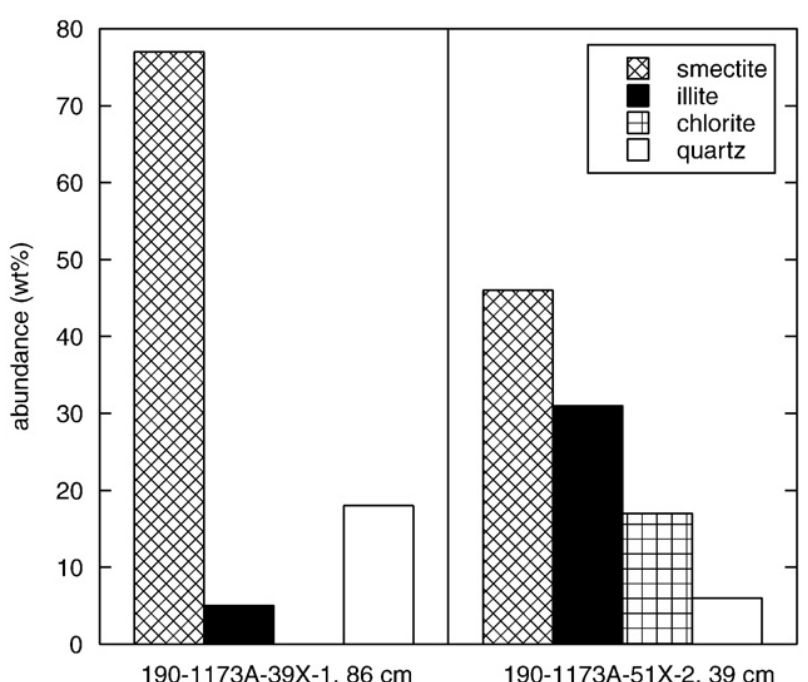

Fig. 5. Relative weight fractions of clay minerals for the two whole-round cores, as determined from measurements on subsamples from the two cores by Steurer and Underwood (2003a).
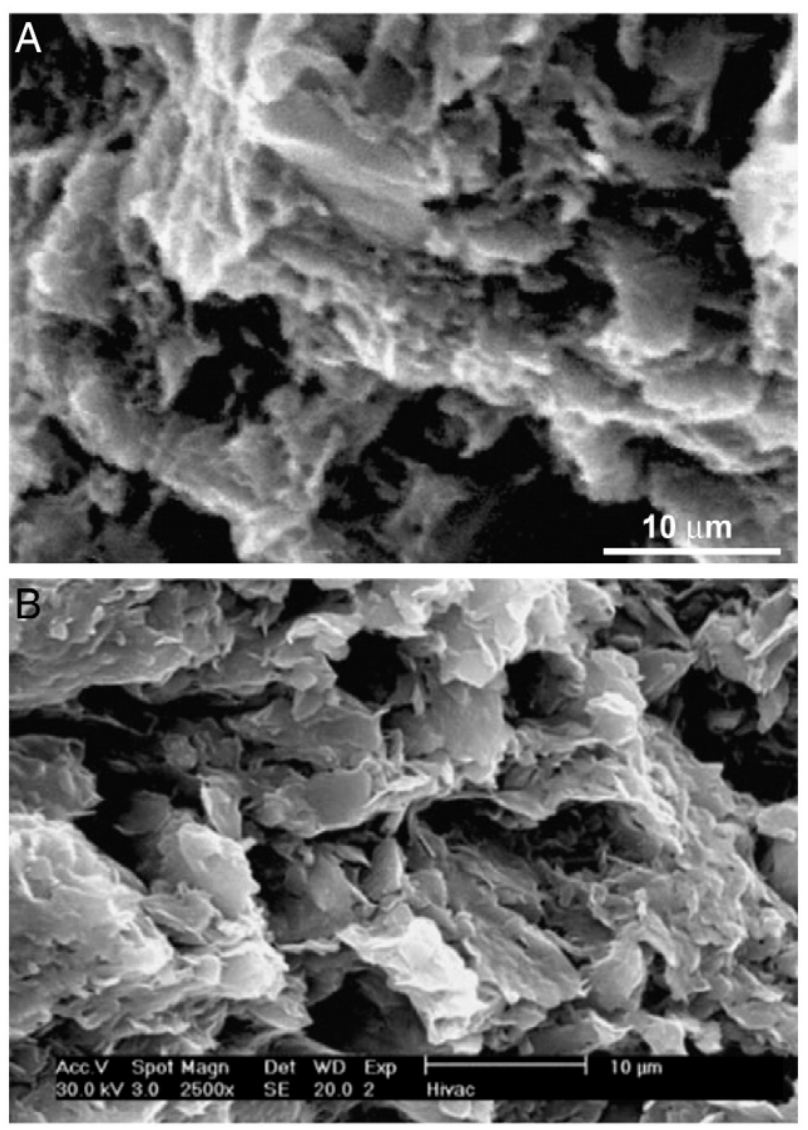

Fig. 6. A, Sample 190-1173A-39X-1, 76-99 cm. B, Sample 190-1173A-51X-2, 42-64 cm. The SEM images of the two samples reveal differences in microfabric. The shallow sample contains stacked aggregates that are separated by more randomly oriented particles. The deep sample has more uniform grain size, moderate clay preferred orientation, and moderate sized secondary pores (from Sunderland and Morgan, 2004; Morgan et al., 2007). moderate sized secondary pores (Fig. 6B; Morgan et al., 2007). Grainsize analyses confirm this latter observation (Steurer and Underwood, 2003b): the results of those analyses propose that the deeper sample consists of $31 \%$ silt- and $69 \%$ clay-sized particles. Unfortunately, no grain-size analyses have been made on the shallow sample. Visual inspection of the shallow sample suggests that the clay content is high in this sample as well, but that a small amount of sand-sized grains also is present in the sample.

\section{Results}

4.1. Tests T121 and T122 (Site 1173, 361 mbsf, above the protodécollement zone)

The sample tested during T121 was subjected to a maximum effective vertical stress, $\sigma_{\mathrm{v}}$ ' of $3.9 \mathrm{MPa}$, a maximum effective horizontal stress, $\sigma_{\mathrm{h}}{ }^{\prime}$ of $1.6 \mathrm{MPa}$, and vertical strain, $\varepsilon_{\mathrm{v}}$ of $2.0 \%$ over about $72 \mathrm{~h}$. The corresponding values for the sample of test T122 were 9.3 MPa, 7.1 MPa, $13.6 \%$, and $190 \mathrm{~h}$, respectively. The variations in average horizontal strain, $\varepsilon_{\mathrm{h}}^{\mathrm{av}}$ and the stress ratio between vertical and volumetric strain $\left(\Delta \varepsilon_{\mathrm{v}} / \Delta \varepsilon_{\mathrm{vol}}\right)$ are measures of how well the uniaxial strain conditions are maintained during testing. With exception for some scattered values, five at the beginning of the test, and three during testing, $\varepsilon_{\mathrm{h}}^{\mathrm{av}}$ range within $\pm 0.01 \%$ during test T121. Furthermore, the mean and standard deviation of $\varepsilon_{\mathrm{h}}^{\mathrm{av}}$ is $0.000 \pm 0.002 \%$ during the test. For test T122, we note that the computer algorithm had difficulties maintaining a constant cross-sectional area, allowing a shear fracture to form and subsequently reactivate (see below). However, the general trend of the experiment matches those of others, indicating it is a valid reconsolidation test. If the erroneous nine values are ignored from the data set, the variations in $\varepsilon_{\mathrm{h}}^{\text {av }}$ lie within acceptable limits, i.e. from -0.01 to $0.00 \%$, and the mean and standard deviation of $\varepsilon_{\mathrm{h}}^{\mathrm{av}}$ is $0.001 \pm 0.001 \%$. Both tests reveal excellent linear correlations between vertical and volumetric strains $\left(\Delta \varepsilon_{\mathrm{v}} / \Delta \varepsilon_{\mathrm{vol}} \approx 1.00 ; R \approx 1.00\right)$. Hence, both the variation of $\varepsilon_{\mathrm{h}}^{\mathrm{av}}$ and the stress ratio of $\Delta \varepsilon_{\mathrm{v}} / \Delta \varepsilon_{\mathrm{vol}}$ show that the cross-sectional area remained constant during testing, with minor exceptions (the very start of test T121 and at shear fracture formation/reactivation of test T122).

In general, the response of the sample during test T122 was generally more uniform than that during test T121 (Fig. 7). The reconsolidation phases I to IIIB of Fig. 3B are recognized in test T122 data. On the other hand, only phases I, II, and the beginning of phase IIIA are identified in plots of test T121 results (Fig. 7).

The elastic reconsolidation response under uniaxial strain conditions (phase II) differs for the two tests in several respects. First, different elastic $K_{0}$ stress ratios were obtained: 0.17 for T121, and 0.11 for T122. Second, test T121 yielded in a ductile manner, whereas test T122 yielded in a brittle manner. A consequence of the brittle yield is that $\sigma_{\mathrm{y}}{ }^{\prime}$ is easily constrained in test $\mathrm{T} 122$; the average of all stress and strain relationships suggests $\sigma_{\mathrm{y}}^{\prime}$ of $3.01 \pm 0.01 \mathrm{MPa}$ (Fig. 7). The various stress and strain plots of T121 are somewhat more complex to interpret. The effective vertical yield stress, $\sigma_{\mathrm{y}}{ }^{\prime}$ is marked by breaks in slopes of the $\sigma_{\mathrm{v}}{ }^{\prime}-\sigma_{\mathrm{h}}{ }^{\prime}$ and $\sigma_{\mathrm{m}}{ }^{\prime}-\Delta \sigma$ plots (Fig. 7A, B), and a more subtle change in the slope of the $\sigma_{\mathrm{v}}{ }^{\prime}-\varepsilon_{\mathrm{v}}$ plot (Fig. $7 \mathrm{C}$ ). These interpretations suggest a $\sigma_{\mathrm{y}}{ }^{\prime}$ of $3.25 \pm 0.10 \mathrm{MPa}$ for the sample of test T121 (Table 2). At 361 mbsf, the effective in situ vertical stress assuming hydrostatic pore pressure, $\sigma_{\mathrm{vh}}{ }^{\prime}$ is $2.2 \mathrm{MPa}$, and the derived maximum effective in situ vertical stress, $\sigma_{v^{*}}^{\max }$ is $3.3 \mathrm{MPa}$ (Table 2). Comparisons between $\sigma_{\mathrm{y}}$ ' and $\sigma_{\mathrm{vh}}$ ' suggest that both samples for tests T121 and T122 behaved as if overconsolidated. The sample of test T121 was subjected to ductile yield, and has $O C R=1.5, P_{*}^{\min }=-1.1$, and $\lambda_{*}^{\min }=-0.5$. Somewhat lower $\sigma_{\mathrm{v}^{*}}^{\max }$ and $O C R$ values, and higher $P_{*}^{\max }$

Fig. 7. Results from samples above the protodécollement, tests T121 and T122. A, Effective vertical stress, $\sigma_{\mathrm{v}}{ }^{\prime}$ plotted against effective horizontal stress, $\sigma_{\mathrm{h}}{ }^{\prime}$. The effective in situ vertical stress for hydrostatic pore pressure, $\sigma_{\mathrm{v}}{ }^{\prime}$ of the sample is shown. B, Differential stress, $\Delta \sigma$ plotted against effective mean stress $\sigma_{\mathrm{m}}{ }^{\prime}$. C, Vertical strain, $\varepsilon_{\mathrm{v}}$ plotted against effective vertical stress, $\sigma_{\mathrm{v}}{ }^{\prime}$. The point of initial sediment yield, $\sigma_{\mathrm{y}}^{\prime}$ is indicated on each plot. 
M.V.S. Ask, J.K. Morgan / Tectonophysics 482 (2010) 50-64
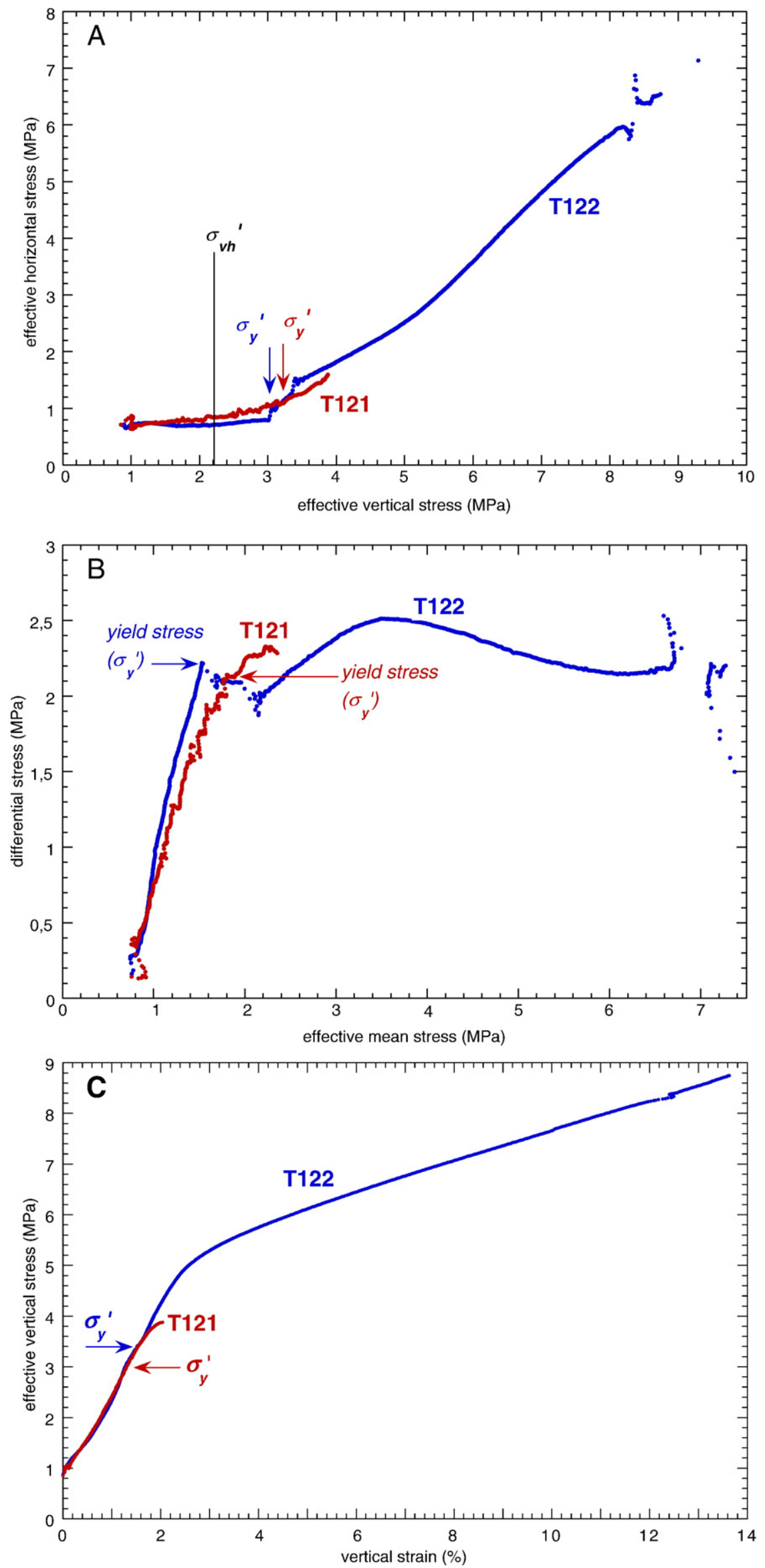
and $\lambda_{*}^{\min }$ values are obtained for the sample of test T122 that yielded in a brittle manner (Table 2). These results would appear to imply the presence of negative pore-fluid pressures (Table 2), although these characteristics are also consistent with enhanced yield strength due to sediment cementation (Morgan and Ask, 2004; Morgan et al., 2007).

The post-yield behavior of test T122 is characterized by a sharp local drop in $\Delta \sigma$ at increasing $\sigma_{\mathrm{m}}{ }^{\prime}$, after which $\Delta \sigma$ increases up to the peak strength, $\Delta \sigma_{\text {peak }}$ of $2.51 \mathrm{MPa}$ (phase IIIA). The remaining part of test T122 is associated with a breakdown of cementation of phase IIIB. At $\sigma_{\mathrm{m}}$ ' of $6.7 \mathrm{MPa}$, there is another sharp drop in $\Delta \sigma$ (Fig. 7B). This drop is interpreted to be caused by reactivation of the shear fracture, and as a result, the test was shut down under controlled conditions. It appears that the reactivation occurred at the onset pf phase IIIC, plastic uniaxial consolidation during normal consolidation (Fig. 7B). Because the shear fracture occurred within the ring of horizontal LVDT's, complete failure of the sample was prohibited by the computer algorithm that maintained the prescribed $K_{0}$ reconsolidation conditions (i.e. constant effective vertical stress increase at uniaxial strain). The angle to the horizontal of the shear fracture, $\beta$ was $\sim 65^{\circ}$, which corresponds to an effective friction angle, $\Phi^{\prime}$ of $40^{\circ}$ and a friction coefficient, $\mu$ of 0.84 (Table 2). Test T121 ended unexpectedly in brittle failure due to the formation of a shear fracture in the lower part of the sample. Because it was formed outside of the ring of horizontal LVDT's, the computer algorithm could not impede in the failure process. The angle of the shear fracture $\beta$ was $\sim 47^{\circ}$, which results in $\Phi^{\prime}$ of $4^{\circ}$ and $\mu$ of 0.07 . This variability in effective friction based on different shear fracture orientations in essentially identical samples, implies some sample in homogeneities, possibly due to sample fabric or to stress heterogeneity during testing.

\subsection{Tests T117 and T123 (Site 1173, 476 mbsf, below the protodécollement zone)}

Test T117 continued for $214 \mathrm{~h}$, during which the sample was deformed up to maximum values of $\sigma_{\mathrm{v}}{ }^{\prime}, \sigma_{\mathrm{h}}{ }^{\prime}, \varepsilon_{\mathrm{v}}$ of $9.5 \mathrm{MPa}, 8.0 \mathrm{MPa}$, and $11.1 \%$, respectively (Fig. 8). Corresponding values for the sample of test T123 were $125 \mathrm{~h}, 6.1 \mathrm{MPa}, 4.6 \mathrm{MPa}$, and $4.9 \%$, respectively. In both tests, values of $\varepsilon_{\mathrm{h}}^{\mathrm{av}}$ vary from -0.01 to $0.01 \%$. The mean and standard deviation of $\varepsilon_{\mathrm{h}}^{\mathrm{av}}$ is $0.001 \pm 0.003 \%$ for test T117, and $0.000 \pm 0.001 \%$ for test T123. While the stress ratio of $\Delta \varepsilon_{\mathrm{v}} / \Delta \varepsilon_{\mathrm{vol}}$ is $1.00(R=1)$ for test $\mathrm{T} 117$, it is only 0.98 for test T123. A small positive shift of $0.002 \%$ in $\varepsilon_{\mathrm{h}}^{\mathrm{av}}$ seems to be responsible for the poor linear fit of the $\Delta \varepsilon_{\mathrm{v}} / \Delta \varepsilon_{\mathrm{vol}}$ stress ratio, and occurred as the test was restarted after a paper jam (at $\sigma_{\mathrm{m}}{ }^{\prime}$ $\sim 3 \mathrm{MPa}$ ). Aside from this shift, all available data suggest that the crosssectional area remained constant during testing as desired.

An additional complication associated with test T117 is the unexpectedly large scatter in $\sigma_{\mathrm{h}}{ }^{\prime}, \Delta \sigma$, and $\sigma_{\mathrm{m}}{ }^{\prime}$, which is the result of an erroneous entry of the initial sample radius. The introduced error in calculated cross-sectional area caused the computer algorithm to increase the rate of $\sigma_{\mathrm{h}}{ }^{\prime}$ oscillations. Fortunately, it appears that the small amplitude of the $\sigma_{\mathrm{h}}{ }^{\prime}$ oscillations $(\sim 0.1 \mathrm{MPa})$ had little effect on the mechanical behavior of the sample. Here, we present only the filtered data, but the results of test T117 are presented in detail in Morgan and Ask (2004), including plots of filtered and unfiltered data. Test T123 is characterized by uniform responses in all recorded parameters, and serves to validate the results of T117. While all reconsolidation phases of Fig. 3B are identified in the data of test T117, part of phase IIIB and the entire phase IIIC are missing in test T123 results (Fig. 8).

The transition from isotropic stress to uniaxial strain conditions (phase I) is completed by $\sigma_{\mathrm{v}}{ }^{\prime}$ values of 1.5 and $1.1 \mathrm{MPa}$ during tests $\mathrm{T} 117$ and T123, respectively. We observe a similar variation in response for tests T117 and T123, as we did for tests T121 and T122
(Figs. 7, 8). First, a lower elastic $K_{0}$ stress ratio of 0.28 is observed for test T123, compared to that of test T117 $\left(K_{0}=0.46\right)$. Second, test T117 yielded in a ductile manner, whereas test T123 yielded in a brittle manner. Interpretation of brittle yield is straightforward, and $\sigma_{\mathrm{y}}$ ' of $2.30 \pm 0.01 \mathrm{MPa}$ is obtained for the sample of test T123 (Table 2). Ductile yield in test T117 is more gradual; nevertheless, it is almost as well constrained $(2.95 \pm 0.03 \mathrm{MPa})$. The effective in situ vertical stress for hydrostatic pore pressure, $\sigma_{\mathrm{vh}}$ ' is $3.3 \mathrm{MPa}$ at $476 \mathrm{mbsf}$ (Table 2). The results of test T117 suggest a slightly underconsolidated $(O C R=0.9)$ sample, with minor excess pore-fluid pressure and overpressure $\left(P_{*}^{\min }=0.4 ; \lambda_{*}^{\min }=0.1\right)$, as the maximum effective in situ vertical stress, $\sigma_{v^{*}}^{\max }$ is $2.9 \mathrm{MPa}$. The substantially lower $\sigma_{\mathrm{y}}^{\prime}$ in test T123 implies an even smaller overconsolidation stress ratio, greater excess porefluid pressure, overpressure, and in situ stress estimation (Table 2).

The post-yield sample response in test T123 is similar to that of test T122, with a local decrease in $\Delta \sigma$ after yield. However, the drop is not quite as abrupt in test T123 as in test T122 (Figs. 7, 8). After the post-yield trough in $\Delta \sigma$ values, the two reconsolidation curves for tests T117 and T123 are very similar, with the difference that the curve from test $\mathrm{T} 117$ is shifted in the positive $\sigma_{\mathrm{m}}{ }^{\prime}$ direction by $\sim 0.4 \mathrm{MPa}$ compared to that of test T123 (Fig. 8B). The two tests reach almost identical values of $\Delta \sigma_{\text {peak }}$ (Table 2). Test T123 was ended prematurely $\left(\sigma_{\mathrm{m}}{ }^{\prime} \sim 5 \mathrm{MPa}\right)$ because of battery failure, before the end of phase IIIB. After the sample of test T117 had reached its peak strength, the sample softened, showing decreasing $\Delta \sigma$ with increasing $\sigma_{\mathrm{m}}$ ' (e.g. phase IIIB, Fig. 3B). A second stage of nearly linear increase in $\Delta \sigma$ follows after $\sigma_{\mathrm{m}}$ ' of $6.2 \mathrm{MPa}$ (phase IIIC), denoting work-hardening as the sample approached primary $K_{0}$ reconsolidation, with a plastic $K_{0}$ stress ratio of 0.82 . Linear extrapolation of the stress ratio to $\sigma$ $\mathrm{h}^{\prime}=0 \mathrm{MPa}$ gives a low value of $\sigma_{\mathrm{v}}{ }^{\prime}=0.20 \mathrm{MPa}$, which suggests the sample is very close to a state of primary consolidation at the end of test T117.

A shear fracture was identified while demounting test T123. The shear fracture occurred within the ring of horizontal LVDT's, and therefore, complete failure of the sample was prohibited by the computer algorithm that managed to maintain the conditions of $K_{0}$ reconsolidation stress path (i.e. constant effective vertical stress increase at uniaxial strain). The angle of the shear fracture to the horizontal, $\beta$ of the shear angle was $67^{\circ}$, which corresponds to an effective friction angle, $\Phi^{\prime}$ of $44^{\circ}$ and a friction coefficient, $\mu$ of 0.97 .

\section{Discussion}

Figs. 7, 8 and Table 2 summarize the results of the four $K_{0}$ reconsolidation tests we conducted on subsamples from two wholeround core samples from 361 and 476 mbsf at Site 1173. The results are surprising in some ways, and lead to some further questions. First of all, both tests on the shallower sample, from $361 \mathrm{mbsf}$, show higher values for $\sigma_{\mathrm{y}}{ }^{\prime}$ than the two tests on deeper samples from 476 mbsf. In addition, their yield strengths are higher than that predicted from $\sigma_{\mathrm{vh}}$ ' at that sample depth. Also unexpectedly, a brittle yield occurred in two of the tests, even though the applied stress path should have been ductile. These observations are relevant to the first and second objectives of this study. After discussing these anomalous behaviors, we will address the three objectives, namely (1) estimation of the effective in situ vertical stress and pore-fluid pressure at the sample depth; (2) construction of a critical state model and yield surface for sediments below the protodécollement, and (3) projection of the mechanical properties from shallow to greater depths.

Fig. 8. Results from samples below the protodécollement, tests T117 and T123. A, Effective vertical stress, $\sigma_{\mathrm{v}}^{\prime}$ plotted against effective horizontal stress, $\sigma_{\mathrm{h}}{ }^{\prime}$. The effective in situ vertical stress for hydrostatic pore pressure, $\sigma_{\mathrm{v}}{ }^{\prime}$ of the sample is shown. B, Differential stress, $\Delta \sigma$ plotted against effective mean stress, $\sigma_{\mathrm{m}}{ }^{\prime}$. C, vertical strain, $\varepsilon_{\mathrm{v}}$ plotted against effective vertical stress, $\sigma_{\mathrm{v}}^{\prime}$. The point of initial sediment yield, $\sigma_{\mathrm{y}}^{\prime}$ is indicated on each plot. 
M.V.S. Ask, J.K. Morgan / Tectonophysics 482 (2010) 50-64
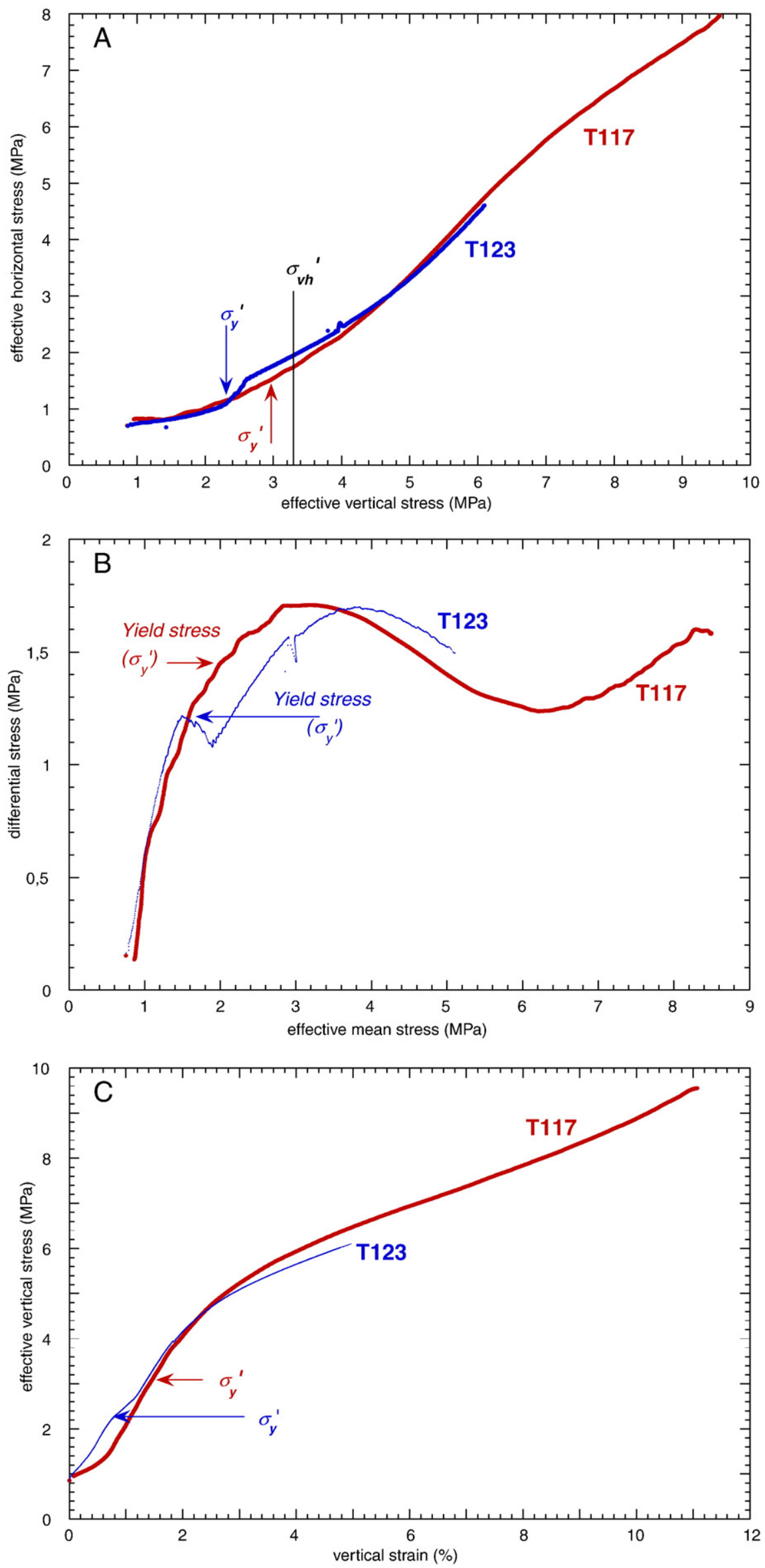


\subsection{Yield- and peak strength behavior}

The test results reveal that the two samples from $361 \mathrm{mbsf}$ have higher strengths and elastic stiffnesses compared to those at $476 \mathrm{mbsf}$, and also compared to their burial depth. While the effective in situ vertical stress for hydrostatic pore pressure $\sigma_{\mathrm{vh}}{ }^{\prime}$ is $1 \mathrm{MPa}$ greater at 476 mbsf than at $361 \mathrm{mbsf}$, the deeper sample exhibits an effective vertical yield stress, $\sigma_{\mathrm{y}}^{\prime} \sim 0.3 \mathrm{MPa}$ lower and peak differential stress, $\Delta \sigma_{\text {peak }} 0.8 \mathrm{MPa}$ lower than those for the shallow sample (Table 2). Furthermore, the elastic $K_{0}$ stress ratio of the shallow sample reveals a stiffer response than in the deeper sample, perhaps a reflection of the $\sim 12-13 \%$ lower porosity relative to the shallow sample (Fig. 2). Based on previous studies, the most likely explanation for the observed and apparently inverted differences in mechanical properties for the two samples from different depths, is contrasting degrees of cementation (e.g. Karig, 1993; Morgan and Ask, 2004; Morgan et al., 2007). Consistent with this interpretation, anomalously high porosities shallower at Site 1173 are interpreted to result from opal cementation (Shipboard Scientific Party, 2001), and various phase transitions consistent with ongoing diagenesis during burial and increasing temperature are predicted at greater depths (Spinelli et al., 2007). As noted by Jones (1994), the mechanical response to overconsolidation and sediment cementation may be difficult to distinguish.

Three parameters may be used to distinguish the responses of overconsolidated materials from cemented materials (Jones, 1994): (1) microscopic identification of cementation, (2) differentiation in elastic $K_{0}$ stress ratio; and (3) large and rapid post-yield deformation of cemented underconsolidated materials. The fine-grained clay phase in SEM images of the shallow sample has been identified as a possible cementing agent (Sunderland and Morgan, 2004; Morgan et al., 2007). This clay phase is absent in the deep sample. However, the elastic $K_{0}$ stress ratio of cemented material tends to be low, whereas it is high in overconsolidated material (Jones, 1994). These results further support that the $K_{0}$ stress ratios of 0.11 and 0.17 obtained in the shallow samples are influenced by cement. The deep sample has significantly higher values of elastic $K_{0}, 0.28$ and 0.46 (Table 2). In comparison, the plastic $K_{0}$ stress ratio of test T117 is 0.82 . The samples tested here do not undergo dramatic failure at yield because of the applied stress path. However, the sample response in phase IIIB that starts at the peak strength, $\Delta \sigma_{\text {peak }}$ reveal significant loss of strength During test T122, sediment strength decreases by about $1 \mathrm{MPa}$ from $\Delta \sigma_{\text {peak }}$ to the end of test T122, which probably precedes the end of phase IIIB (Fig. 7B; Table 2). During test T117, the corresponding drop for the entire phase IIIB is about $0.50 \mathrm{MPa}$ (Fig. $8 \mathrm{~B}$; Table 2). Hence, the drop in strength in the deep sample is only about half of the loss of strength in the shallow sample.

The clay mineralogy also differs for the two samples (Fig. 5). The shallow sample from $361 \mathrm{mbsf}$ has one of the highest abundances of smectite ( $77 \mathrm{wt} . \%$ ) throughout the entire Site 1173 , with quartz being the second most abundant mineral. A fine-grained clay phase that may correspond with this smectite is observed in the SEM images in the shallow sample, but not in the deeper sample (Fig. 6) (Sunderland and Morgan, 2004; Morgan et al., 2007). Smectite is the most abundant clay mineral in the deep sample from $476 \mathrm{mbsf}$ as well, but the second most abundant mineral in this sample is illite, which is absent in the $361 \mathrm{mbsf}$ sample. This implies that in the deep sample, the smectiteillite transformation has nearly gone to completion, in contrast to the shallow sample (e.g. Steurer and Underwood, 2003a). The smectite probably is authigenic, formed by dissemination of ash layers (Steurer and Underwood, 2003a). Authigenic smectite grows at grain boundaries, and has a substantial impact on sediment physical properties (Tribble and Wilkens, 1994) and stiffness (Dadey et al., 1991). On the one hand, its high water content results in low grain density, friction coefficient, cohesive strength, and high porosity (e.g. Bird, 1984, Tribble and Wilkens, 1994). On the other hand, sufficient strength and rigidity of a smectite-rich matrix may preserve open pores that remain after glass dissolution to depths greater than 560 mbsf in Site 808 (Tribble and Wilkens, 1994). Additional strength of the shallow sample may be provided by randomly oriented particles, in comparison to the deep sample that has a more uniform grain size and a distinct particle preferred orientation (Sunderland and Morgan, 2004; Morgan et al., 2007).

\subsection{Elastic behavior}

Two of the four tested samples underwent brittle yield during reconsolidation, despite the restrictions on lateral sample strain due to the prescribed uniaxial strain conditions. The remaining two samples underwent ductile yield, as anticipated. Nonetheless, all of the samples revealed relatively stiff elastic responses (Figs. 7, 8). The low elastic $K_{0}$ values in the shallower samples may be explained by the combined effect of differences in cement, microfabric and mineralogy, in contrast to those from 476 mbsf (Table 2). Interestingly, samples that yielded in a brittle manner (tests T122 and T123) also have lower $K_{0}$ values than those that underwent ductile yield.

We propose that local and minor variation in pore-fluid pressure and initial test conditions may determine whether the sample will yield in a ductile or brittle manner, in addition to small-scale variations in cement, microfabric, and mineralogy. The two tests that underwent brittle yield, also reached yield at lower values than those that underwent ductile yield, suggesting that they actually intersected different parts of the yield envelope, c.f. Fig. 3A. As noted above, the boundary between these two modes is the critical state line (CSL), implying that these tests may inadvertently constrain the position of this key feature.

\subsection{Construction of a critical state model}

The critical state concept and yield surface defined in $3 \mathrm{D} \sigma_{\mathrm{m}}{ }^{\prime}-\Delta \sigma-$ volume space figure provide a framework within which all aspects of the deformation of porous sediments can be described and effectively interrelated (e.g. Schofield and Wroth, 1968; Atkinson and Bransby, 1978; Wood, 1990; Jones, 1994). The nature of the yield surface and critical state line in 3D are relatively well understood for uncemented sediments, and summarized in Fig. 9A. The yield surface consisting of the Hvorslev (brittle) and Roscoe (ductile) surfaces is separated by the critical state line (CSL). The expanding yield surface with decreasing porosity (or void ratio) and increasing $\Delta \sigma$ and $\sigma_{\mathrm{m}}$ ', captures the strong dependence of sediment strength on these properties, as well as the stress path followed through this space.

The appropriate yield surface for cemented sediments is less well understood, and no doubt varies with associated sediment properties. Reasonably, the same general critical state model shown in Fig. 9A applies for cemented materials (Jones, 1994), but must take into account the enhanced strengths prior to both brittle and ductile failure, particularly at high porosities and high $\sigma_{\mathrm{m}}$ ' values. However, as the sediment state evolves during deformation through destructuring and disaggregation, the yield surface will also change, ultimately merging with the uncemented surface (e.g., Fig. 9B). Furthermore, during elastic loading of a sample during reconsolidation, porosity change is initially small, justifying the projection of the resulting stress path into a $2 \mathrm{D}$ space defined by $\sigma_{\mathrm{m}}{ }^{\prime}$ and $\Delta \sigma$ (e.g. Fig. $3 \mathrm{~A}$ ). This logic allows us to try to construct a representative $2 \mathrm{D}$ section through the yield surface for the sub-décollement sample from the Nankai margin probed during the two tests T117 and T123. Fig. 10 maps the constraints from the tests to outline the probable yield surface. This is the first effort to constrain the three primary components of critical state mechanics for Nankai sediments, i.e., the natural stress path (i.e. plastic $K_{0}$ stress ratio), the yield envelope, and the critical state line. Because a theoretically correct $2 \mathrm{D}$ section captures the $\sigma_{\mathrm{m}}{ }^{\prime}$ and $\Delta \sigma$ variation at constant porosity, Fig. 10 only approximates this theoretical 2D plot thanks to the small changes in porosity during testing until $\Delta \sigma_{\text {peak }}$, and more significant changes beyond $\Delta \sigma_{\text {peak }}$. 
Sediments at Site 1173 are initially deposited on the incoming oceanic plate, seaward of the accretionary deformation front (Shipboard Scientific Party, 2001). These sediments are thus assumed to have a simple stress history characterized by uniaxial compaction along the $K_{0}$ reconsolidation stress path, controlled by self-weight burial beneath the
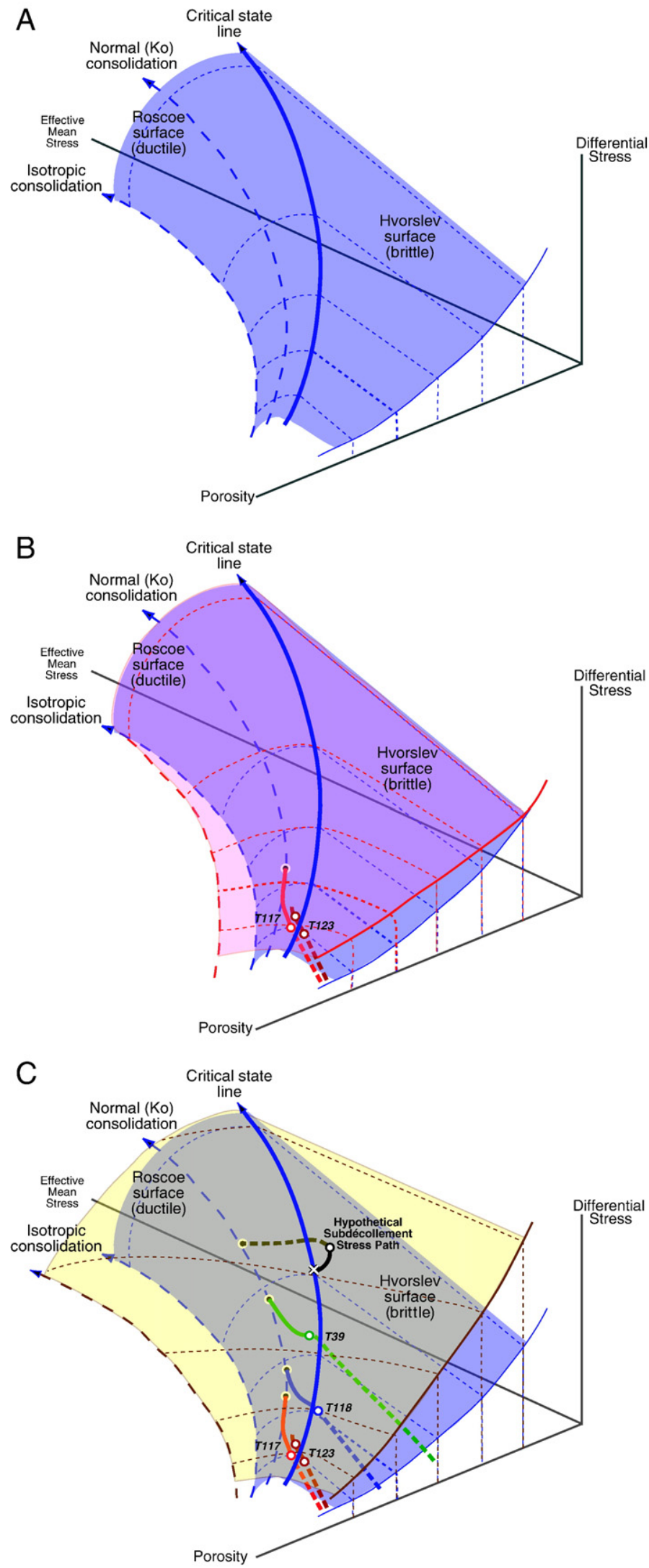

overlying sediments; horizontal deformation is restricted by the surrounding sediments (e.g. Karig, 1993; Morgan et al., 2007). Only one test successfully collected data of the plastic $K_{0}$ stress ratio, i.e., test T117 (Table 2). This stress ratio appears to approximate that of primary consolidation to higher than in situ stresses (Morgan and Ask, 2004). The natural stress path defining a $K_{0}$ stress ratio of 0.82 is shown in Fig. 10 (number 1).

Ideally, the yield surface is constrained from a suite of tests along different stress paths on an essentially identical samples (e.g. Schofield and Wroth, 1968; Atkinson and Bransby, 1978; Wood, 1990; Jones, 1994). The yield surface is believed to be approximately elliptical, and centered along the natural stress path. Our original intention of repeating the same stress path twice at each depth with similar initial stress conditions was to obtain a measure of the redundancy of testing. The two tests reveal on one hand good repeatability, especially with respect to $\Delta \sigma_{\text {peak }}$ and the initial porosity of the subsamples. On the other hand, we obtained two slightly different elastic $K_{0}$ reload paths and different values for $\sigma_{\mathrm{y}}{ }^{\prime}$, which may reflect small-scale variations in cement and microfabric, small-scale pore pressure variations, and/or differences in initial stress conditions at the computer-controlled onset of testing (see above). The unexpected outcome is that rather than getting only one repeated point on the yield surface, we obtained two points. In addition, because one subsample yielded in a brittle manner while the other yielded in a ductile manner, we also may have constrained the location of the critical state line that separates the two fields (see below). The two yield points are shown in Fig. 10 (number 2 ), together with their symmetrical counterparts on the opposite side of the natural stress path (number 3 of Fig. 10).

We further propose that an additional yield point can be obtained from test T123, which experienced a drop in $\Delta \sigma$ after the yield stress was attained. This stress drop seems to have returned the sample into the elastic regime, after which work-hardening occurred until a second "yield" was reached at $\Delta \sigma_{\text {peak }}$ (number 4 of Fig. 10). The peak strength corresponds to the initial disruption of the cemented fabric of the rock (e.g. Jones, 1994). Its symmetrical counterpart of $\Delta \sigma_{\text {peak }}$ is shown in Fig. 10 (number 5). We note that the test results from test T117 during phase IIIA (from $\sigma_{\mathrm{y}}{ }^{\prime}-\Delta \sigma_{\text {peak }}$ ) and the test results from test T123 during phase IIIB (beyond $\Delta \sigma_{\text {peak }}$ ) both fall on the same yield envelope. Cleary, further tests are necessary to determine if this is purely coincidental or if it follows the yield surface of the cement, i.e. if the cement breakdown is occurring at the uppermost limit of natural states (e.g. Jones and Addis, 1986; Jones, 1994).

The critical state line should be constrained by the ductile yield of test T117 and the brittle yield of test T123. In addition, the angle of the shear fracture from test T123, $\beta$, also provides an estimate of the critical state line, because the slope of the critical state line in the stress path plot, $M$ is related to $\beta$ and, hence, the friction coefficient, $\mu$ (Table 2) (Wood, 1990). The solid gray line of Fig. 10 (number 6) shows the slope of the critical state line based on the calculation of $M$ from $\beta$ and $\mu$, which coincides with the graphical estimation in the

Fig. 9. Schematic 3D critical state models. A 3D critical state model of uncemented sediment. The blue yield surface consists of the Hvorslev (brittle) and Roscoe (ductile) surfaces that are divided by the critical state line. Two ductile stress paths are included, isotropic and normal $\left(K_{0}\right)$ consolidation. B, 3D critical state model for a single sample of cemented sediment. The cemented yield surface in red is projected over the uncemented yield surface. We propose that the two yield surfaces will merge at elevated stress states due to the breakdown of cement. The stress paths of tests T117 and T123 are included. C, 3D critical state model for multiple samples of cemented sediment. A composite yield surface in yellow based on the accumulated results of several tests is projected over the uncemented yield surface. The orange and red stress paths of Site 1173 tests (T117, T123) are complemented by blue and green stress paths of tests landward of the deformation front in Sites 1174 (test T118) and 808 (test T39), respectively. Test T39 is sketched to continue onto the normal consolidation line; however, test T39 was terminated before it reached its peak strength (Karig, 1993). The black curve reveals a hypothetical stress path that a sediment from below the décollement may follow when the sediment reaches critical state, i.e. fault-slip in an earthquake. 


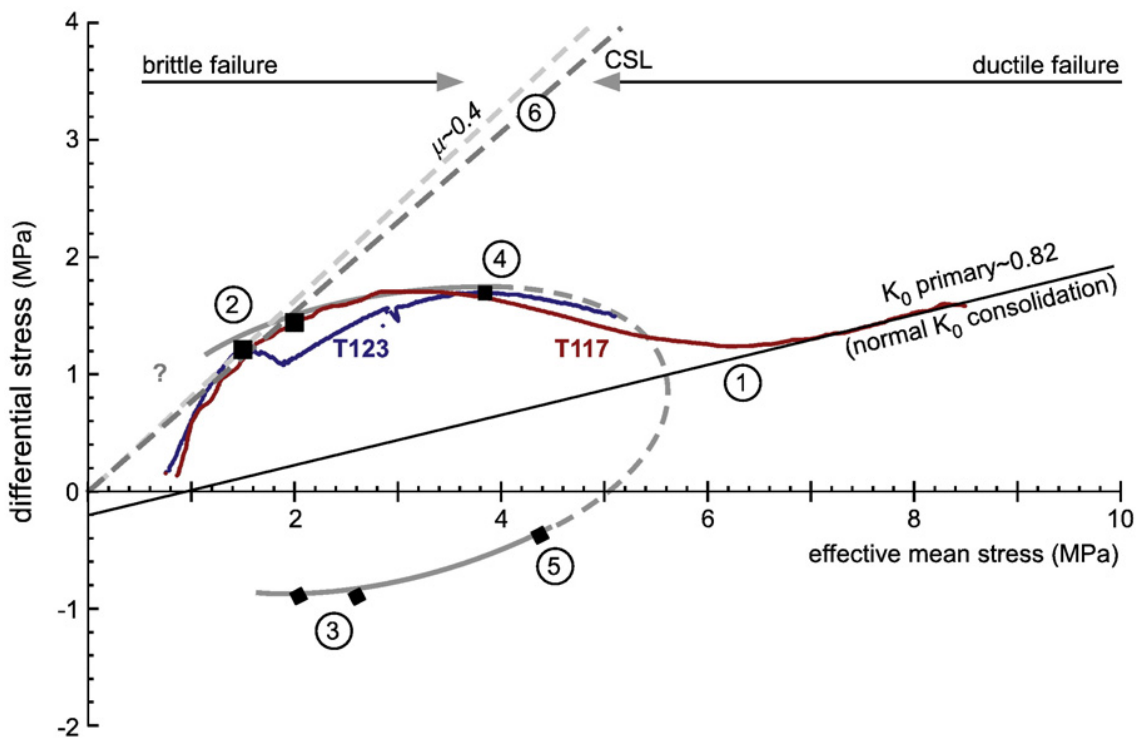

Fig. 10. Construction of the yield envelope in the stress path plot $\left(\sigma_{\mathrm{m}}^{\prime}-\Delta \sigma\right)$ using the results from tests T117 and T123. (1), Natural stress path of samples, measured during $K_{0}$ primary consolidation; (2), ductile and brittle yield stresses of tests T117 and T123, respectively; (3), the symmetrical counterparts of (2); (4) the peak strength of test T123 may sample the yield envelope; (5), the symmetrical counterpart of (4), and (6) critical state line as defined from the angle of shear fracture of sample after test T123, and graphical determination. The friction coefficient of Bourlange et al. (2004) is included.

plot (i.e. by fitting a line from $\Delta \sigma=\sigma_{\mathrm{m}}{ }^{\prime}=0 \mathrm{MPa}$ to in between the two yield points). Also included in number 6 of Fig. 10 is a dotted line $(\mu \sim 0.4)$, which is the result from a drained triaxial test on a clay sample from 620 mbsf in Site 1173 (Bourlange et al., 2004).

As noted above, Fig. 10 is not exactly a constant porosity 2D representation of $\sigma_{\mathrm{m}}$ ' and $\Delta \sigma$. Fig. 9B shows a schematic representation of the stress paths for tests T117 and T123 in the 3D critical state model, demonstrating the associated porosity loss after yield. Initially, both stress paths climb through the elastic field bypassing the uncemented yield surface (blue), until they encounter the cemented yield surface (red). Initial brittle failure occurs on the Hvorslev surface for test T123, and the subsequent decrease in $\Delta \sigma$ with increasing $\sigma_{\mathrm{m}}{ }^{\prime}$ causes the path to pass below the CSL, re-emerging along the ductile surface, and subsequently dipping below the initial cemented surface as the cement breaks down to approach the $K_{0}$ line on the uncemented surface (blue). Test 117, in contrast, passes below the CSL before yield, and undergoes initial ductile yield, precipitating a decrease in $\Delta \sigma$ as it migrates on to the uncemented $K_{0}$ line.

\subsection{Projection of mechanical properties from shallow to greater depths}

The hypothetical cemented yield surface shown in Fig. 9B is inferred for a single sample with a unique strength profile and post-yield behavior dependent on its in situ state seaward of the Nankai deformation front. Previous studies, however, suggest that sediments beneath the décollement become stronger with burial and time, due to ongoing diagenesis (Morgan and Ask, 2004; Morgan et al., 2007). If this is the case, then a yield surface for a single sample cannot be projected to depth with accuracy, but rather a composite surface must be generated based on the accumulated results of tests carried out on deeper samples (e.g. Fig. 9C). Two previous test results carried out on two subsamples collected from greater depths beneath the Nankai décollement at Sites 1174 and 808 provide additional data points (Fig. 1) (Karig, 1993; Morgan and Ask, 2004). The Site 1174 sample (test T118) from $881 \mathrm{mbsf}$ had a lower porosity (37\%), higher effective yield stress (4.95 MPa), and a peak strength of nearly $6 \mathrm{MPa}$, more than 3 times that of T117 and T123 (Morgan and Ask, 2004; this study). During reconsolidation, this sample underwent ductile yield prior to porosity collapse, and also approached the $K_{0}$ line before the test was terminated. The Site 808 sample (test T39) from 1098 mbsf had the lowest porosity ( 30\%) and the highest effective yield stress (6.40 MPa). This test was terminated before the peak strength was reached (Morgan and Ask, 2004). Many aspects of this representation of the depth-varying yield surface in Fig. $9 \mathrm{C}$ are purely speculative, however. Further tests on deeper samples will help to constrain how sediment strength will increase with burial, in excess of strengths inferred from in situ porosity conditions.

In reality, the stress paths that sediments will follow during tectonic failure at depth will differ from those explored in the laboratory. It is likely that the stress path outside of the deformation front of the Nankai accretionary prism is gravitational (e.g. Karig and Morgan, 1994). Tectonic loading will have progressively higher influence on sediment consolidation landward of the deformation front. Nevertheless, the condition of uniaxial strain is believed to be maintained in sediments below the décollement (Karig and Morgan, 1994; Screaton et al., 2002). This idea is supported by the absence of tectonic grain fabrics within these sediments (e.g. Brückmann et al., 1993; Morgan and Karig, 1993). The taper wedge is small until 30-40 km landward of the deformation front, beyond which it increases dramatically (e.g. Moore et al., 2001). It is likely that the in situ sediments below the décollement at latest are perturbed by tectonic loading at this stage, e.g. décollement downcutting and/or seismic stresses. If such an event results in sudden increases in pore pressure and deviatoric stress, the stress path will return to the elastic field with decreasing $\sigma_{\mathrm{m}}$ ', likely causing brittle failure as $\Delta \sigma$ increases, followed by local disaggregation along the resulting fault plane to the CSL (e.g. Fig. 9C).

The true stress paths cannot be predicted with certainty at this time, but with further deformation experiments of the type presented here, we have the potential to better constrain the appropriate yield surface that will apply through space and time, to better predict the stress conditions that lead to sediment failure and post-failure behavior. In reality, the stress paths that sediments will follow during tectonic failure at depth will differ from those explored in the laboratory. Such stress paths are also influenced by time-dependent deformation (i.e., creep, or secondary consolidation; i.e. Karig and Ask, 2003), thermal consolidation (Hüpers and Kopf, 2009), and chemical aspects of deformation (e.g. Steurer and Underwood, 2003a).

\section{Conclusions}

We have obtained intriguing results form reconsolidation tests that we have carried out on sediments collected from above and below the protodécollement in Site 1173 of the Nankai margin. From 
their large scale behavior, our tests show that the samples collected above the protodécollement have higher strength than those below. It seems likely that authigenic smectite cement and distinguishing microfabrics are responsible for their higher strengths. Consequently, these shallow samples cannot be used reliably to estimate the magnitude of in situ stresses.

The sediments below the protodécollement are normally consolidated to slightly underconsolidated. For these sediments, the maximum effective vertical stress is similar or slightly lower than at hydrostatic pressure.

We have used the results from the tests on samples collected below the protodécollement horizon to make the first attempt to construct the yield surface for a sample of a given porosity. The compilation of further tests over a range of depths beneath the Nankai décollement will allow this model to be extrapolated to a wider range of sediment states, taking into consideration variations in porosity and stressinduced hardening, as well as time and temperature dependent diagenetic strengthening. Ultimately, further tests on a wide range of samples will be needed to verify these findings.

\section{Acknowledgments}

This research used samples and data provided by the Ocean Drilling Program (ODP), collected during ODP Leg 190. ODP is sponsored by the U.S. National Science Foundation (NSF) and participating countries under management of Joint Oceanographic Institutions (JOI), Inc. Shorebased experiments were conducted at Cornell University. Dan Karig provided insightful comments and gave us access to his laboratory, and George Hade is gratefully thanked for engineering assistance that formed the basis for the well-functioning test equipment. Ask received funding for this research from the Swedish Research Council Grants 2003-6527 and 2003-6527, and Luleå University of Technology. We thank Dave Dewhurst, CSIRO Petroleum, Australia, Achim Kopf, Bremen University, Germany, an unknown reviewer and the guest editor Mark Tingay, for their thoughtful and careful reviews, which have led to an improved version of this manuscript.

\section{References}

Ando, M., 1982. A fault model of the 1946 Nankaido earthquake derived from tsunami data. Physics of the Earth and Planetary Interiors 28, 320-336.

Atkinson, J.H., Bransby, P.L., 1978. The Mechanics of Soils, an Introduction to Critical State Soil Mechanics. McGraw-Hill, New York, USA. 375 pp.

Bangs, N.L.B., Gulick, S.P.S., 2005. Physical properties along the developing decollement in the Nankai Trough; inferences from 3-D seismic reflection data inversion and Leg 190 and 196 drilling data. [online]. In: Mikada, H., Moore, G.F., Taira, A., Becker, K., Moore, J.C., Klaus, A. (Eds.), Proceedings ODP scientific results, 190/196. College Station, TX (Ocean Drilling Program), pp. 1-27. doi:10.2973/odp.proc.sr.190196.354.2005.

Becker, D.E., Crooks, J.H.A., Been, K., Jeffries, M.G., 1987. Work as a criterion for determining in situ and yield stresses in clays. Canadian Geotechnical Journal 24, 549-564. doi:10.1139/t87-070.

Bird, P., 1984. Hydration-phase diagrams and friction of montmorillonite under laboratory and geologic conditions, with implications for shale compaction, slope stability, and strength of fault gouge. Tectonophysics 107, 235-260.

Bjerrum, L., 1973. Problems of soil mechanics and construction of soft clays and structurally unstable soils (collapsible, expansive and others). : Proceedings of the 8th International Conference on Soil Mechanics and Foundation Engineering, vol. 3. A.A. Balkema, Moscow, CCCP, pp. 111-159. Rotterdam, the Netherlands.

Bourlange, S., Jouniaux, L., Henry, P., 2004. Data report: permeability, compressibility, and friction coefficient measurements under confining pressure and strain, Leg 190, Nankai Trough. Proceedings ODP scientific results, 190/196. College Station, TX (Ocean Drilling Program), pp. 1-16. doi:10.2973/odp.proc.sr.190196.215.2004.

Bray, C.J., Karig, D.E., 1986. Porosity of sediments in accretionary prisms and some implications for dewatering processes. Journal of Geophysical Research 90, 768-778

Brückmann, W., Moran, K., Taylor, E., 1993. Acoustic anisotropy and microfabric development in accreted sediment from the Nankai Trough. In: Hill, LA., Taira, A., Firth, JV et al. (Eds.), Proceedings ODP scientific results, 131, College Station, TX (Ocean Drilling Program), pp. 221-233. doi:10.2973/odp.proc.sr.131.121.1993.

Burland, J.B., 1990. On the compressibility and shear strength of natural clays. Géotechnique 40, 329-378.

Casagrande, A., 1936. The determination of pre-consolidation load and its practical significance. Proceedings of the 1st International Conference on Soil Mechanics and
Foundation Engineering, vol. 3. A.A. Balkema, Cambridge, Massachusetts, USA, pp. 60-64. Rotterdam, the Netherlands.

Dadey, K.A., Leinen, M., Silva, A.J., 1991. Anomalous stress history of sediments of the Northwest Pacific: the role of microstructure. In: Bennett, R.H., Bryant, W.R., Hulbert, M.H. (Eds.), Microstructure of Fine-Grained Sediments, From Mud to Shale. Springer, New York, USA, pp. 229-236.

Dugan, B., Flemings, P.B., 2000. Overpressure and fluid flow in the New Jersey continental slope: implications for slope failure and cold seeps. Science 289, 288-291.

Farmer, I., 1983. Engineering Behaviour of Rocks2nd ed. Chapman \& Hall, London, United Kingdom. 208 pp.

Flemings, P.B., Long, H., Dugan, B., Germaine, J., John, C.M., Behrmann, J.H., Sawyer, D., Expedition 308 Scientists, IODP, 2008. Pore pressure penetrometers document high overpressure near the seafloor where multiple submarine landslides have occurred on the continental slope, offshore Louisiana, Gulf of Mexico. Earth and Planetary Science Letters 269, 309-325. doi:10.1016/j.epsl.2007.12.005.

Gulick, S.P.S., Bangs, N.L.B., Shipley, T.H., Nakamura, Y., Moore, G., Kuramoto, S., 2004. Three-dimensional architecture of the Nankai accretionary prism's imbricate thrust zone off Cape Muroto, Japan: prism reconstruction via en echelon thrust propagation. Journal of Geophysical Research 109, B02105. doi:10.1029/2003JB002654.

Hüpers, A., Kopf, A.J., 2009. The thermal influence on the consolidation state of underthrust sediments from the Nankai margin and its implications for excess pore pressure. Earth and Planetary Science Letters 286, 324-332.

Jones, M.E., 1994. Mechanical principles of sediment deformation. In: Maltman, A. (Ed.), The geological deformation of sediments. Chapman \& Hall, London, United Kingdom, pp. 37-71.

Jones, M.E., Addis, M.A., 1986. The application of stress path and critical state analysis to sediment deformation. Journal of Structural Geology 8, 575-580.

Karig, D.E., 1993. Reconsolidation tests and sonic velocity measurements of clay-rich sediments from the Nankai Trough. In: Hill, LA., Taira, A., Firth, J.V., et al. (Eds.), Proceedings ODP scientific results, 131, College Station, TX (Ocean Drilling Program), pp. 247-260. doi:10.2973/odp.proc.sr.131.127.1993.

Karig, D.E., Morgan, J.K., 1994. Tectonic deformation: stress paths and strain histories. In: Maltman, A. (Ed.), The Geological Deformation of Sediments. Chapman \& Hall, London, United Kingdom, pp. 167-204.

Karig, D.E., Ask, M.V.S., 2003. Geological perspectives on consolidation of clay-rich marine sediments. Journal of Geophysical Research 108 (2197), 1-14. doi:10.1029/ 2001JB000652.

Kimura, G., Screaton, E.J., Curewitz, D., and the Expedition 316 Scientists, 2008. NanTroSEIZE Stage 1A: NanTroSEIZE shallow megasplay and frontal thrusts. Integrated Ocean Drilling Program preliminary report, 316. doi:10.2204/iodp.pr.316.2008. 59 pp.

Leddra, M.J., Petley, D.N., Jones, M.E., 1992. Fabric changes induced in a cemented shale through consolidation and shear. In: Tillerson, J.R., Wawersik, W.R.W. (Eds.), Rock Mechanics, Proceedings of the 33rd U.S. Symposium. Rotterdam. A.A. Balkema, the Netherlands, pp. 917-926.

Moore, G.F., Karig, D.E., Shipley, T.H., Taira, A., Stoffa, P.L., Wood, W.T., 1991. Structural framework of the ODP Leg 131 area, Nankai Trough. In: Taira, A., Hill, I., Firth, J.V., et al. (Eds.), Proceedings ODP initial reports, 131. College Station, TX (Ocean Drilling Program), pp. 15-20. doi:10.2973/odp.proc.ir.131.102.1991.

Moore, G.F., Taira, A., Klaus, A., et al., 2001. Proceedings ODP initial reports, 190. College Station, TX (Ocean Drilling Program). doi:10.2973/odp.proc.ir.190.2001.

Morgan, J.K., Karig, D.E., 1993. Ductile strains in clay-rich sediments from Hole 808C preliminary results using X-ray pole goniometry. In: Hill, LA., Taira, A., Firth, J.V. et al. (Eds.), Proceedings ODP scientific results, 131. College Station, TX (Ocean Drilling Program), pp. 141-155. doi:10.2973/odp.proc.sr.131.112.1993.

Morgan, J.K., Karig, D.E., 1995. Kinematics and a balanced and restored cross-section across the toe of the eastern Nankai accretionary prism. Journal of Structural Geology 17, 31-45.

Morgan, J.K., Ask, M.V.S., 2004. Consolidation state and strength of underthrust sediments and evolution of the décollement at the Nankai accretionary margin: results of uniaxial reconsolidation experiments. Journal of Geophysical Research 109 (B03102), 1-20. doi:10.1029/2002JB002335.

Morgan, J.K., Sunderland, E.B, Ask, M.V.S., 2007. Deformation and diagenesis at the Nankai subduction zone: implications for sediment mechanics, décollement initiation, and propagation. In: Dixon, T.H., Moore, J.C. (Eds.), The Seismogenic Zone of Subduction Thrust Faults. Columbia University Press, New York, USA, pp. 210-256.

O 'Brien, D.K., Manghnani, M.H., Tribble, J.S., 1989. Irregular trends of physical properties in homogeneous clay-rich sediments of DSDP Leg 87, Hole 584, Midslope terrace in the Japan Trench. Marine Geology 87, 183-194.

Obara, K., 2002. Nonvolcanic deep tremor associated with subduction in southwest Japan. Science 296, 1679-1681.

Schofield, A.N., Wroth, C.P., 1968. Critical State Soil Mechanics. (McGraw-Hill), New York, USA. 310 pp.

Screaton, E., Saffer, D., Henry, P., Hunze, S., 2002. Porosity loss within the underthrust sediments of the Nankai accretionary complex: implications for overpressures. Geology 30, 19-22.

Seno, T., Stein, S., Gripp, A.E., 1993. A model for the motion of the Philippine sea plate consistent with NUVEL-1 and geological data. Journal of Geophysical Research 98 , 17941-17948

Shipboard Scientific Party, 2001. Site 1173. In: Moore, G.F., Taira, A., Klaus, A., et al. (Eds.), Proceedings ODP initial reports, 190. College Station, TX (Ocean Drilling Program), pp. 1-147. doi:10.2973/odp.proc.ir.190.104.2001.

Spinelli, G.A., Mozley, P.S., Tobin, H.J., Underwood, M.B., Hoffman, N.W., Bellew, G.M., 2007 Diagenesis, sediment strength, and pore collapse in sediment approaching the Nankai Trough subduction zone. Geological Society of America Bulletin 119, 377-390.

Steurer, J.F., Underwood, M.B., 2003a. Clay mineralogy of mudstones from the Nankai Trough reference sites 1173 and 1177 and frontal accretionary prism site 1174 . 
Proceedings ODP scientific results, 190/196, 1-37. College Station, TX (Ocean Drilling Program). doi:10.2973/odp.proc.sr.190196.211.2003.

Steurer, J.F., Underwood, M.B., 2003b. Data report: the relation between physical properties and grain-size variations in hemipelagic sediments from Nankai Trough. Proceedings ODP scientific results, 190/196, 1-37. College Station, TX (Ocean Drilling Program), doi:10.2973/odp.proc.sr.190196.210.2003.

Sunderland, E.B., Morgan, J.K., 2004. Microstructural variations in sediments from the toe of the Nankai accretionary prism: results of scanning electron microscope analysis [online]. In: Mikada, H., Moore, G.F., Taira, A., Becker, K., Moore, J.C., Klaus, A. (Eds.), Proceedings ODP scientific results, 190/196. College Station, TX (Ocean Drilling Program), pp. 1-27. doi:10.2973/odp.proc.sr.190196.212.2004.

Taira, A., Hill, I., Firth, J.V., et al., 1991. Proceedings ODP initial reports, 131. College Station, TX (Ocean Drilling Program). doi:10.2973/odp.proc.ir.131.1991.
Tobin, H.J., Kinoshita, M., 2006. NanTroSEIZE: the IODP Nankai Trough seismogenic zone experiment. Scientific Drilling 2, 23-27. doi:10.2204/iodp.sd.2.06.2006.

Tribble, J., Wilkens, R.H., 1994. Microfabric of altered ash layers, ODP Leg 131, Nankai Trough. Clays and Clay Minerals 42, 428-436.

Ujiie, K., Hisamitsu, T., Taira, A., 2003. Deformation and fluid pressure variation during initiation and evolution of the plate boundary décollement zone in the Nankai accretionary prism. Journal of Geophysical Research 108 (2398), 1-14. doi:10.1029/ 2002JB002314.

Wang, L.B., Frost, J.D., 2004. Dissipated strain energy method for determining preconsolidation pressure. Canadian Geotechnical Journal 41, 760-768. doi:10.1139/T04-013.

Wood, D.M., 1990. Soil Behaviour and Critical State Soil Mechanics. Cambridge University Press, New York, USA. 462 pp. 